Phylogenetic Implications of Pollen Ultrastructure in the Oldfieldioideae (Euphorbiaceae) Author(s): Geoffrey A. Levin and Michael G. Simpson

Source: Annals of the Missouri Botanical Garden, Vol. 81, No. 2 (1994), pp. 203-238

Published by: Missouri Botanical Garden Press

Stable URL: http://www.jstor.org/stable/2992094

Accessed: 13-04-2015 18:50 UTC

Your use of the JSTOR archive indicates your acceptance of the Terms \& Conditions of Use, available at http://www.jstor.org/page/info/about/policies/terms.jsp

JSTOR is a not-for-profit service that helps scholars, researchers, and students discover, use, and build upon a wide range of content in a trusted digital archive. We use information technology and tools to increase productivity and facilitate new forms of scholarship. For more information about JSTOR, please contact support @ jstor.org. 


\section{PHYLOGENETIC IMPLICATIONS OF POLLEN ULTRASTRUCTURE IN THE OLDFIELDIOIDEAE (EUPHORBIACEAE $)^{1}$}

\section{ABSTRACT}

The pollen structure of members of Euphorbiaceae subfamilies Oldfieldioideae and Phyllanthoideae was studied using scanning and transmission electron microscopy in order to assess taxonomic relationships. We identified 10 palynological characters that appear to have systematic significance. We also identified 37 characters of vegetative morphology and anatomy, mostly based on data obtained by Hayden, and five characters of reproductive morphology, based on data in the literature. Cladistic analysis of the Oldfieldioideae along with selected genera in the Phyllanthoideae, using various putative relatives of the Euphorbiaceae as outgroups, provided great insight into the phylogeny of the Oldfieldioideae. Synapomorphies of this subfamily are all palynological: brevicolporate to pororate or porate apertures, echinate sculpturing, and exine with the interstitium consisting of columellae discontinuous from the foot-layer (where present). With the exception of Croizatia, the basal member of the subfamily, all Oldfieldioideae also share the synapomorphies of four or more pollen apertures and no petals; two homoplastic synapomorphies, an exinous footlayer that is irregular to absent and a caruncle on the seeds, also characterize these genera. A clade consisting of Paradrypetes and Podocalyx is supported by the synapomorphies of an extremely reduced pollen exine interstitium and sclerified crystalliferous axial xylem parenchyma, whereas the remaining Oldfieldioideae share the synapomorphies of a "microperforate/baculate" tectum consisting of numerous closely appressed rod-shaped elements, some of which are continuous with the columellae and/or echinae; uniformly simple perforation plates; and alternate intervascular pitting. These Oldfieldioideae represent two clades, taxonomically recognized as the tribes Picrodendreae and Caletieae. The Picrodendreae are diagnosed by the synapomorphy of alternate, circular vessel-ray pitting, and except for Tetracoccus, the basal member of the clade, also share four additional synapomorphies, all foliar: compound or unifoliolate leaves, well-developed bundle sheath extensions, fimbriate marginal ultimate venation, and well-developed areoles. Within the Picrodendreae, synapomorphies distinguish a South American clade and an African/Madagascan/ Indian clade, but do not resolve the position of Oldfieldia within the Picrodendreae. The Caletieae share the synapomorphy of stomatal subsidiary cells that have a crenulate (rather than straight) wall nearest the stomatal pore. Within the tribe, the African genus Hyaenanche is the basal member, with the remaining genera, all of which are Australasian, being united by the synapomorphy of chambered foliar epidermal cells. The Australasian genera comprise two major clades, but the relationships among these clades and Petalostigma are ambiguous. In addition to clarifying relationships within the Oldfieldioideae, these results (1) support the transfer of Croizatia and Paradrypetes from the Phyllanthoideae to the Oldfieldioideae, (2) support inclusion of Scagea, despite its single ovule/locule, in the Oldfieldioideae, (3) demonstrate that Androstachys and Stachyandra are bona fide members of the Oldfieldioideae rather than belonging in their own family, and (4) indicate that Neoroepera, as currently circumscribed, is diphyletic. We propose a revised classification of the subfamily in which all suprageneric taxa are monophyletic according to this phylogeny.

\footnotetext{
${ }^{1}$ We extend our warmest thanks to John Hayden, who generously shared his data and thoughts with us as we pursued our study. Without his generous cooperation, our work would have been far less complete. We accept full responsibility for any interpretations that may differ from his. We thank the curators at DAV, GH, K, MO, P, QRS, RSA/POM, and US for removing or allowing us to remove pollen from collections in their care. Jon Blevitt, Kitty Huntley, and Nicki Watson embedded and sectioned much of the pollen for EM and printed most of the plates. Discussion at the International Conference on the Systematics of the Euphorbiaceae provided valuable insights. We thank Grady Webster and Mike Huft for inviting us to participate. Mike Huft and an anonymous reviewer made valuable comments on an earlier version of this paper. Levin thanks Rick Brusca and Regina Wetzer of Marine Invertebrates Department, San Diego Natural History Museum, for allowing him use of their Apple computers, and Mark Donnelly of the Exhibits Department, San Diego Natural History Department, for help with the cladogram illustrations. He saves his greatest thanks for Mike Simpson, without whose generous sharing of pollen expertise and cladistic insight this research would not have been possible. This research was supported in part by a San Diego State University Foundation Grant-in-aid Award to MGS.

${ }^{2}$ Department of Botany, San Diego Natural History Museum, P.O. Box 1390, San Diego, California 921 12, U.S.A. Current address: Center for Biodiversity, Illinois Natural History Survey, 607 East Peabody Drive, Champaign, Illinois 61820, U.S.A.
}

${ }^{3}$ Department of Biology, San Diego State University, San Diego, California 92182, U.S.A.

AnN. Missouri Bot. Gard. 81: 203-238. 1994. 
Light microscopy (LM) of pollen morphology in the Euphorbiaceae (Erdtman, 1952: 165-175; Punt, 1962; Köhler, 1965) has been particularly influential in the development of recent classifications of the family (e.g., Webster, 1975, 1994). More recently, researchers have begun using scanning electron microscopy (SEM) to study pollen of Euphorbiaceae, and though no comprehensive surveys have yet been published, several papers have treated a variety of genera throughout the family, but especially from subfamilies Phyllanthoideae and Oldfieldioideae (Bonnefille \& Riollet, 1980; Dechamps et al., 1985; El-Ghazaly \& Raj, 1986; Hayden et al., 1984; McPherson \& Tirel, 1987; Poole, 1981; Punt, 1980, 1987; Webster, 1984; Webster et al., 1987). However, only two studies of Euphorbiaceae pollen (Hayden et al., 1984; Poole, 1981) have utilized transmission electron microscopy (TEM) to describe the details of exine architecture, and these papers treated only five genera.

We initiated a study of pollen ultrastructure in the Phyllanthoideae and Oldfieldioideae to help resolve intergeneric relationships. These two subfamilies have two ovules in each locule, which is generally regarded as the plesiomorphic condition in contrast to the single ovule per locule found in the remaining three subfamilies. Of the two biovulate subfamilies, Phyllanthoideae is by far the larger and presumably is paraphyletic and basal to the Oldfieldioideae and the uniovulate subfamilies (Webster, 1967, 1975, 1994; Webster et al., 1987).

Details of our pollen study will be published elsewhere (Simpson \& Levin, in press). Here we present an overview and phylogenetic analysis of the results, concentrating on the Oldfieldioideae. To evaluate pollen characters and better understand relationships within the subfamily, we also include a phylogenetic analysis of vegetative morphological and anatomical data compiled by Hayden $(1980,1994$, this issue) and of selected reproductive characters.

\section{Materials AND MethodS}

TAXA

We examined 40 species in 34 genera with LM and TEM; many of these genera we also examined with SEM (Table 1). Nine genera are members of the Phyllanthoideae sensu Webster (1994), selected to represent the major lineages that have been recognized by prior researchers (e.g., Köhler, 1965; Webster, 1975, 1994; Levin, 1986c). We included Amanoa guianensis and Securinega durissima because they have echinate pollen reminiscent of pollen of Oldfieldioideae (Webster, 1984; Webster et al., 1987). In addition, we examined Didymocistus Kuhlm. because its leaf morphology resembles that of Hymenocardia Wallich ex Lindley (Levin, 1986a, b, c) and its wood differs significantly from that of the Aporuseae (Mennega, 1984, 1987), the tribe in which Webster (1975), following Kuhlmann (1940), placed Didymocistus. Our selection of Oldfieldioideae includes 25 genera. We chose not to section pollen of Austrobuxus and Picrodendron because Hayden et al. (1984) published excellent LM, SEM, and TEM photographs of the pollen of these genera. (We note in passing that the pollen Hayden et al. identified as Austrobuxus carunculatus (Baillon) Airy Shaw came from specimens McPherson \& Tirel (1987) cited as A. brevipes Airy Shaw.) Thus we have pollen ultrastructure information on 27 of the 28 genera Webster (1994) included in the Oldfieldioideae. Like Webster (1994), we accept Paragelonium as a synonym of Aristogeitonia (Radcliffe-Smith, 1987b) and Stachyandra as distinct from Androstachys (Radcliffe-Smith, 1990). We have been unable to get pollen of Canaca, a dubious segregate from Austrobuxus (Webster, 1994).

\section{SPECIMEN PREPARATION}

Flowers from dried herbarium specimens (cited in Table 1) were rehydrated at room temperature in 1\% Aerosol OT for 3-5 days, then fixed and stored in F.A.A. (formalin/acetic acid/ethanol). For LM studies pollen was cleared in Hoyer's mounting medium (Radford et al., 1974) on a microscope slide preparation. LM observations were made using differential interference contrast optics on a Nikon Microphot-FX photomicroscope.

For SEM observations, whole anthers were first dehydrated to $100 \%$ ethanol, then gradually infiltrated to $100 \%$ methylal (dimethoxymethane) or Freon 113. Anthers were then placed in a metal capsule and critical point-dried (with a Tousimis critical point dryer) using pressurized carbon dioxide as the transition fluid. Pollen grains were tapped onto a stub covered with double-stick tape, sputter-coated with gold/palladium (using a Hummer-4 sputtering apparatus), and photographed on a Hitachi S500 scanning electron microscope. We also examined SEM photographs generously loaned by G. L. Webster.

For TEM observations, whole anthers or isolated pollen were fixed in cold $4 \%$ glutaraldehyde in 0.1 M Sorensen's phosphate buffer for 2 hours, fol- 


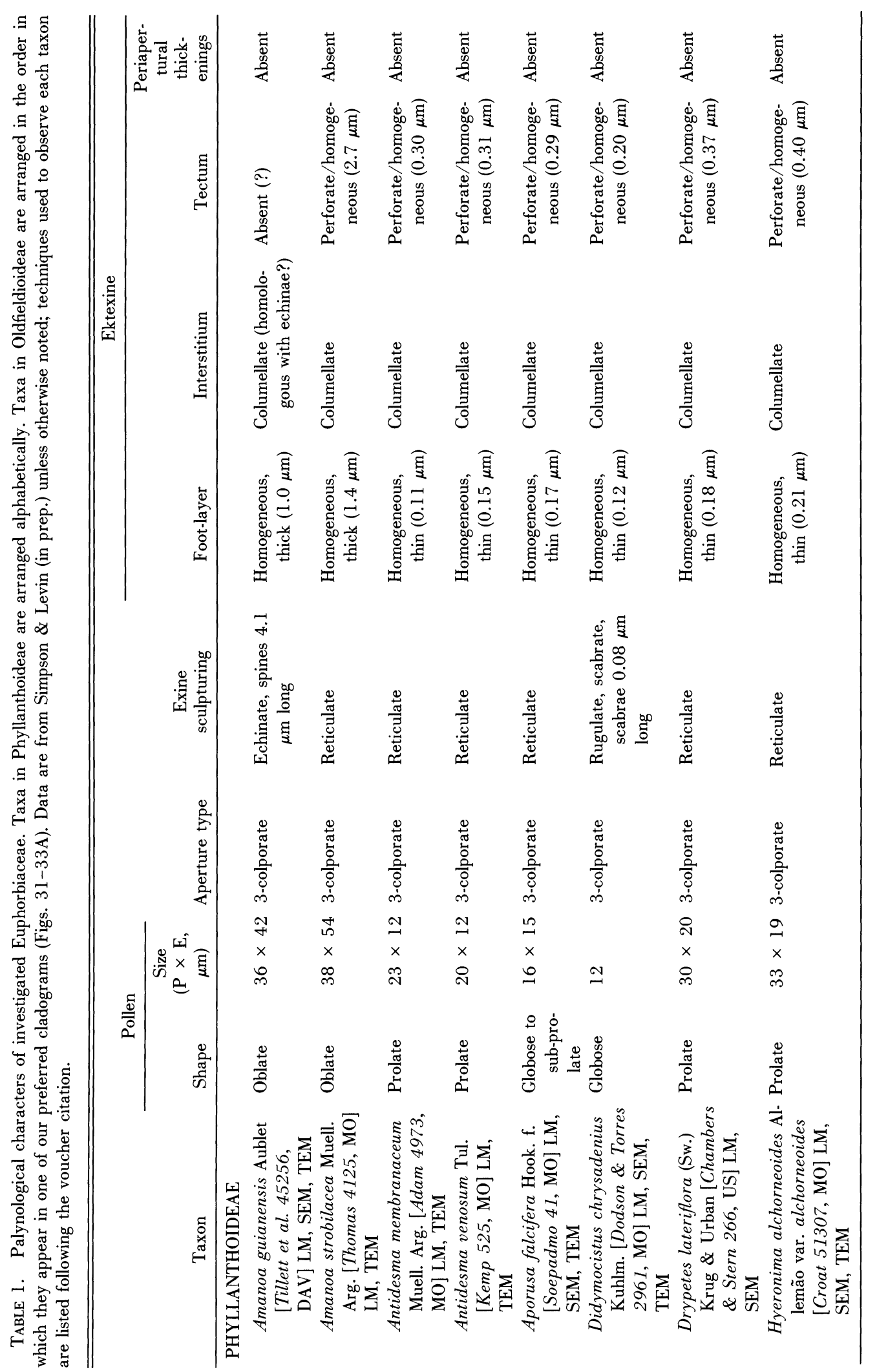




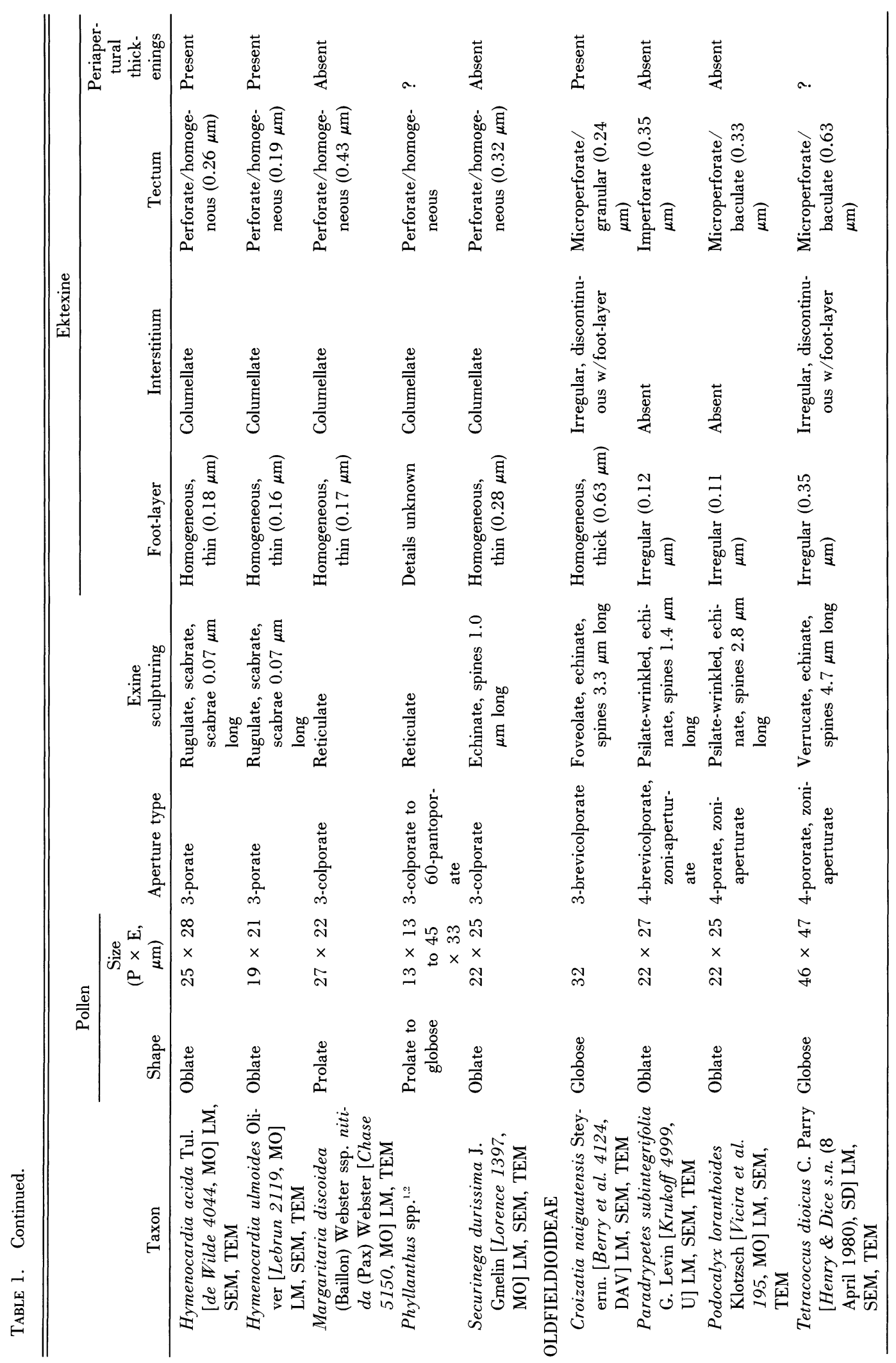




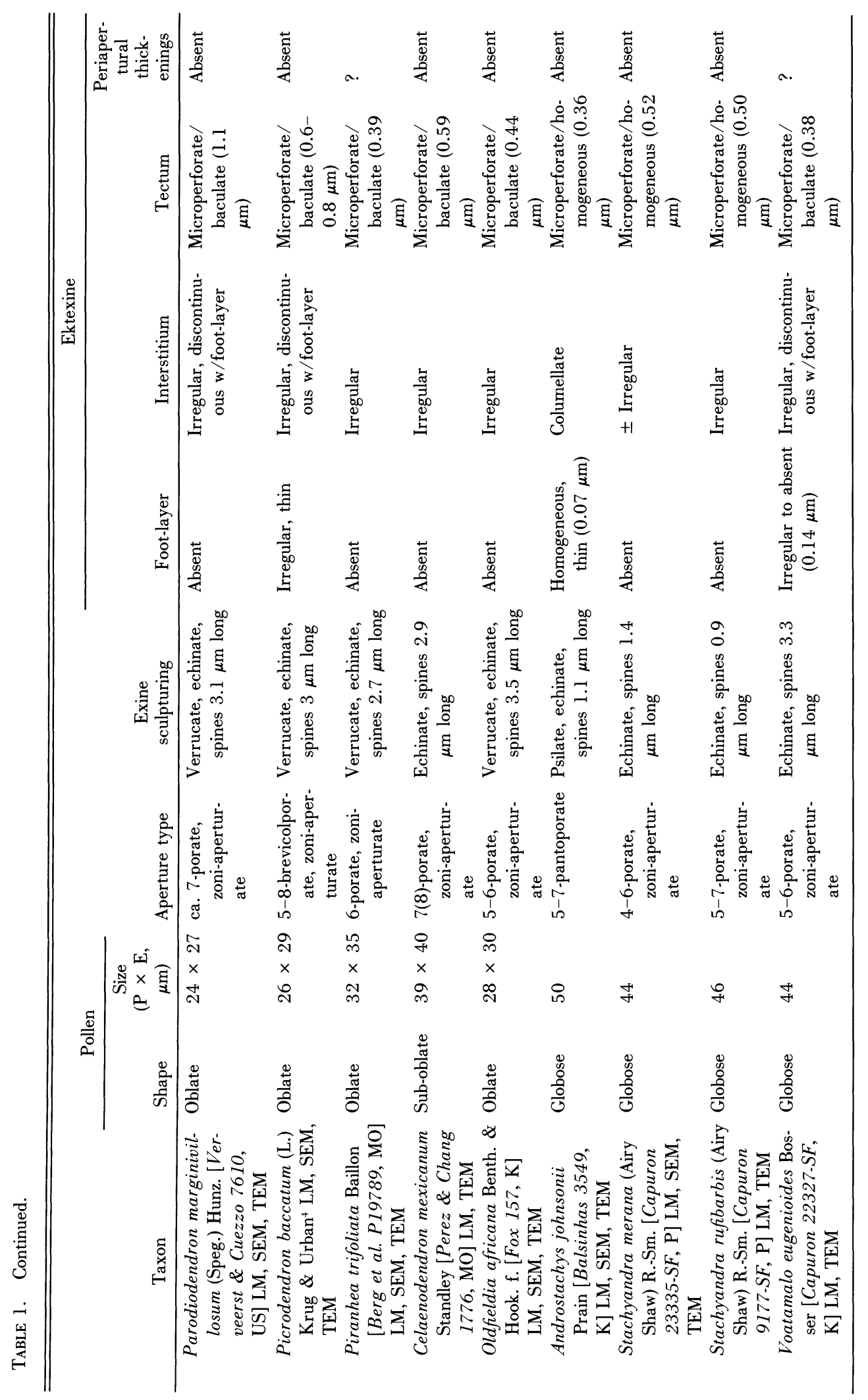




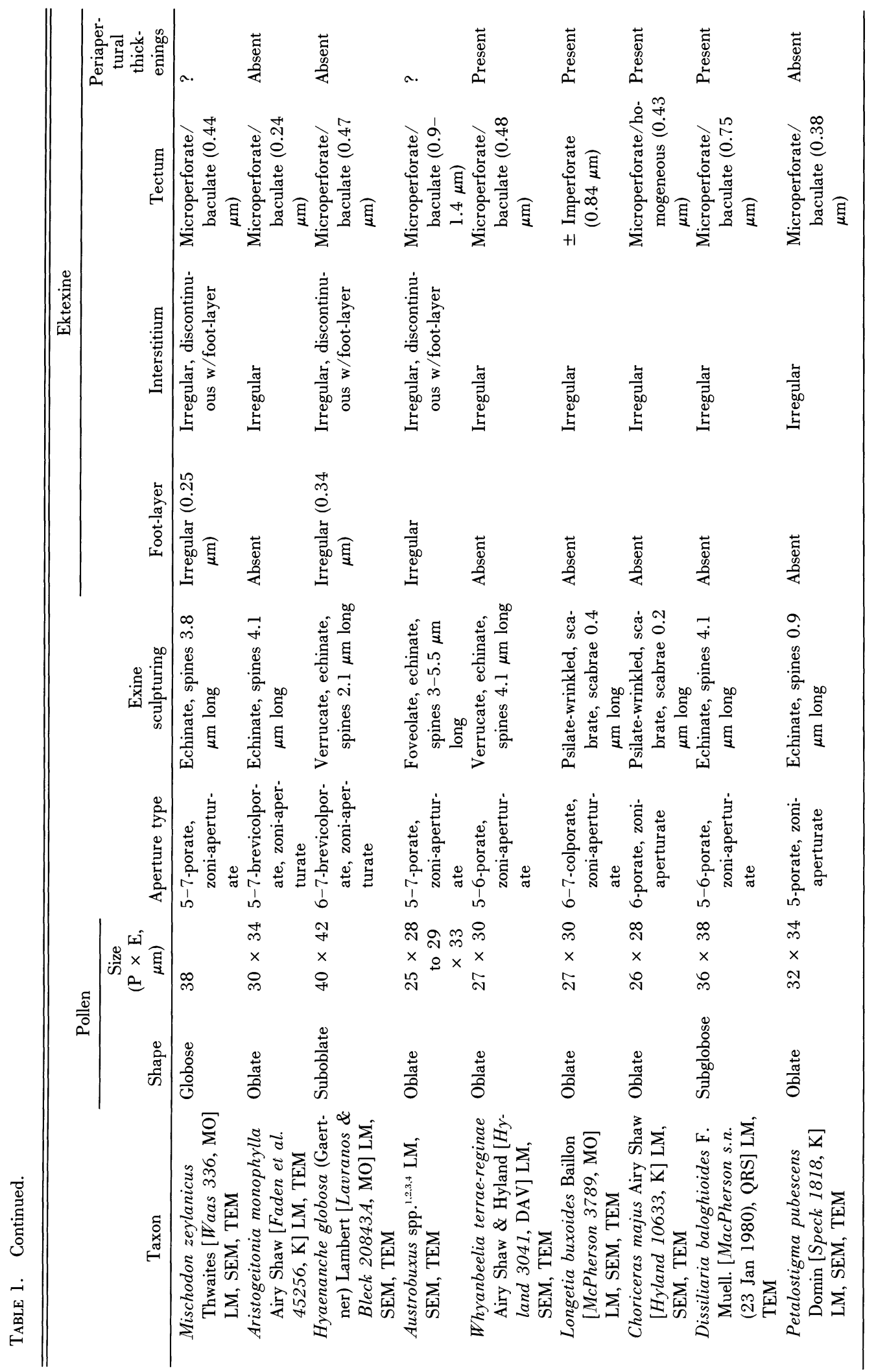




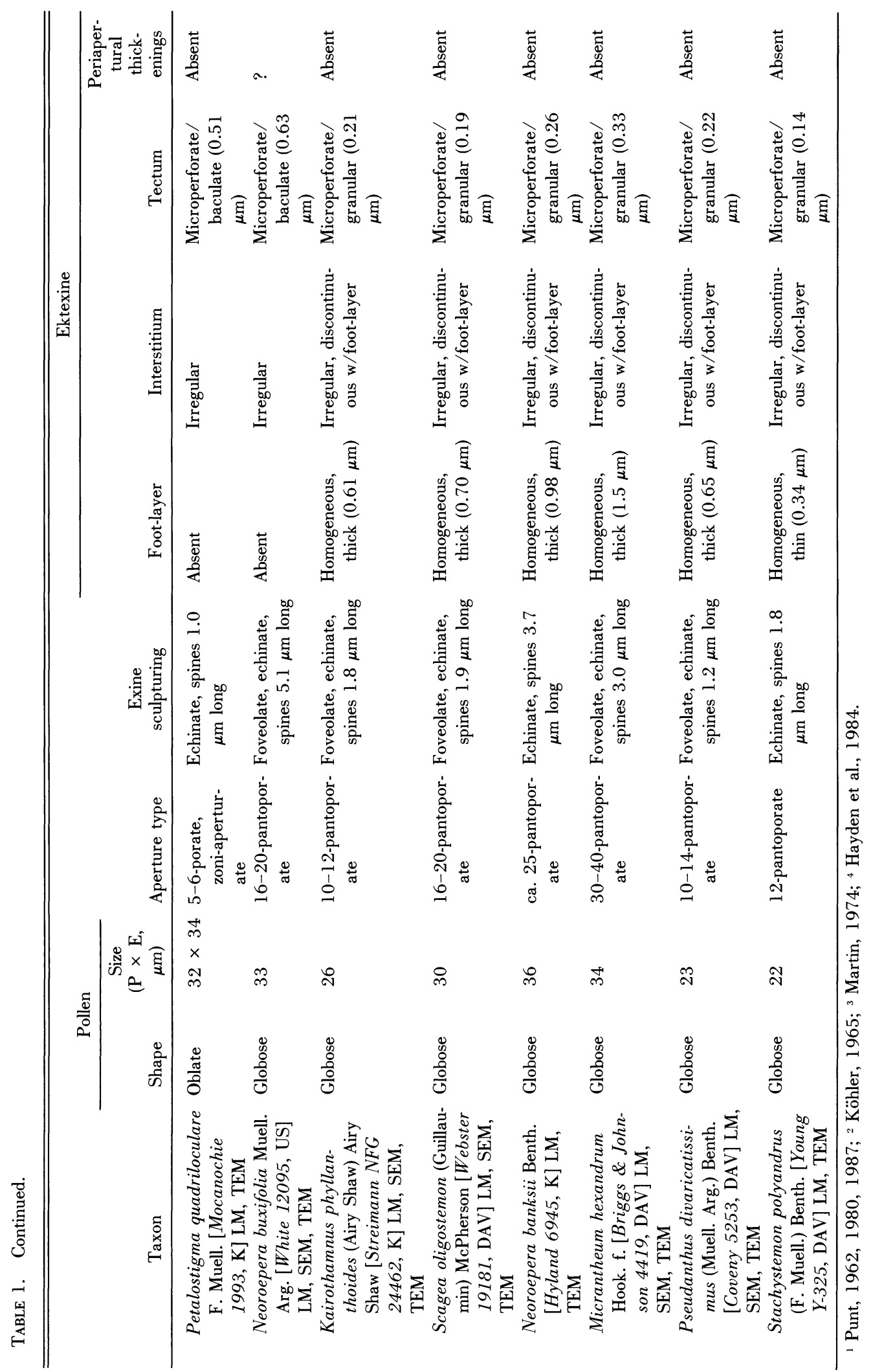


lowed by several rinses in buffer and further fixation in $2 \%$ osmium tetroxide for 2 hours. The material was then quickly rinsed twice in buffer, progressively dehydrated to $100 \%$ ethanol, and infiltrated (via a gradation series) with Spurr's resin (Spurr, 1969). The material was polymerized in BEEM capsules at $65^{\circ} \mathrm{C}$ for $12-18$ hours. Sections 0.5 $\mu \mathrm{m}$ thick were stained with $1 \%$ toluidine blue and mounted on a slide for light microscope observations. Anthers were then ultrathin-sectioned (ca. $95 \mathrm{~nm}$ thick) using a Diatome diamond knife on a Reichert Ultracut-E ultramicrotome, mounted on uncoated hexagonal 200 mesh copper grids, and post-stained with uranyl acetate (saturated solution in $50 \%$ ethanol, 15 minutes) and lead citrate $(0.2 \%$ aq., 7 minutes). To inhibit stain precipitation, grids were gently and quickly washed in a running stream of filtered, distilled water between and after poststaining changes. Observations and photographs were made on a Phillips EM 410 transmission electron microscope.

\section{PHYLOGENETIC ANALYSIS}

We analyzed our data using Wagner parsimony as implemented by PAUP version 3.1 (Swofford, 1993) and HENNIG86 version 1.5 (Farris, 1988). With PAUP we performed heuristic searches (options Mulpars, Maxtree $=250$, and Hold $=5$ ) starting with both closest and random (10 replicates) addition sequences followed by tree bisectionreconnection (TBR) branch-swapping. With HENNIG86 we used the options whennig* and $b b$ to implement similar branch swapping. In addition, we iteratively used the options xsteps $w$ and ccodes followed by whennig and $b b$ to explore the effect of Farris's (1969) sequential weighting of characters, in which the weight of each character is adjusted according to its homoplasy on the previously generated trees. We analyzed character changes on alternative trees using MacClade version 3.0 (Maddison \& Maddison, 1992).

\section{Results AND Discussion}

\section{CHARACTER DEFINITION}

The characters and character states used in our cladistic analysis are listed in Table 2 . Of the 52 characters, 45 are binary characters. We treated all but one of the seven multistate characters as unordered. The exception is character 24, leaf blade; see below for an explanation of how we coded this character. The following is a discussion of the rationale for our decisions of character/character state definition for the palynological, selected veg- etative morphological and anatomical, and reproductive morphological characters.

Palynological characters. Table 1 summarizes the pollen morphology of the genera we examined, supplemented by other published accounts. More detailed information can be found in Simpson \& Levin (in prep.). We recognized 10 palynological characters.

1. Pollen shape. This character distinguishes taxa such as Hyeronima (Figs. 1, 2) that have strongly prolate grains (polar axes longer than equatorial axes) from those such as Neoroepera (Figs. 3, 4), Parodiodendron (Figs. 5, 6), Androstachys (Figs. 7, 8), Micrantheum (Figs. 9, 10), and Pseudanthus (Figs. 11, 12), that have grains ranging from globose to oblate (equatorial axes longer than polar axes). We combined the latter two shape types in a single character state because of the lack of a clear discontinuity between globose, suboblate, and oblate shapes (see Table 1).

2. Pollen aperture number. The number of pollen apertures is either three (e.g., Hyeronima, Figs. 1, 2) or more than three (e.g., Neoroepera, Figs. 3, 4; Androstachys, Figs. 7, 8). We selected the presence of three apertures as a character state because of its widespread occurrence among the dicotyledons (Walker \& Doyle, 1975). For those taxa with more than three apertures, the number ranges from four (e.g., Paradrypetes; Levin, 1992: fig. 1) to 20 or more (e.g., Neoroepera, Figs. 3, 4; Micrantheum, Figs. 9, 10; see also Table 1). Because we could see no clear discontinuity in aperture numbers among these latter taxa, we treated the presence of 4-20 or more apertures as a single character state.

3. Aperture position. This character distinguishes between zoni-aperturate grains (apertures present only along the equatorial plane; e.g., Hyeronima, Fig. 1) and pan-aperturate grains (apertures positioned throughout surface; e.g., Neoroepera, Figs. 3, 4; Pseudanthus, Figs. $11,12)$.

Reports on aperture number and distribution of Androstachys differ considerably. Erdtman (1952: 167) described the pollen as polyforate, i.e., pantoporate with more than 12 apertures (not oligoforate, i.e., with 12 or fewer pores, as misquoted by Dahlgren \& van Wyk, 1988), with the pores faintly defined and covered with granulate membranes. Köhler (1965), studying the same sample, described the pollen as more-or-less pantoporate 
TABLE 2. Characters and character states used in cladistic analysis of the Euphorbiaceae.

1. Pollen shape: $0=$ oblate-globose; $1=$ prolate.

2. Aperture number: $0=3 ; 1=>3$.

3. Aperture position: $0=$ zoni-aperturate; $1=$ panaperturate.

4. Aperture shape: $0=$ colporate; $1=$ brevicolporateporate.

5. Sculpturing (spinal): $0=$ absent; $1=$ minute $(<0.5$ $\mu \mathrm{m}) ; 2=$ large $(>0.9 \mu \mathrm{m})$.

6. Sculpturing (nonspinal): $0=$ reticulate; $\mathrm{l}=$ foveolate; $2=$ rugulate; $3=$ verrucate; $4=$ psilate-wrinkled.

7. Foot-layer: $0=$ homogeneous/thin; $1=$ homogeneous/thick; 2 = irregular-absent.

8. Interstitium: $0=$ continuous with foot-layer; $1=$ discontinuous with foot-layer; $2=$ absent.

9. Tectum: $0=$ perforate $/$ homogeneous $; 1=$ microperforate/homogeneous; $2=$ microperforate/baculate; 3 = microperforate/granular; $4=$ imperforate; $5=$ absent.

10. Ektexinous periapertural thickenings: $0=$ absent; 1 $=$ present.

11. Porosity: $0=$ diffuse; $1=$ ring.

12. Perforation plates: $0=$ mixed scalariform and simple; $1=$ all simple.

13. Intervascular pits: $0=$ transitional; $l=$ alternate.

14. Intervascular pits: $0=$ small, $l=$ larger.

15. Fibers: $0=$ nonseptate; $1=$ septate.

16. Rays: $0=$ heterocellular; $1=$ homocellular erect.

17. Rays: $0=$ not aggregate; $1=$ aggregate.

18. Vessel-ray pits: $0=$ irregular shape and pattern; 1 = circular and alternate.

19. Crystalliferous ray cells: $0=$ unsclerified; $1=$ sclerified.

20. Axial parenchyma: $0=$ present; $l=$ absent.

21. Crystalliferous axial xylem parenchyma: $0=$ sclerified; 1 = unsclerified.

22. Secondary phloem sclerenchyma: $0=$ present; $1=$ absent.

23. Cotyledons: $0=$ wider than radicle; $1=$ narrower than radicle.

24. Leaf blade: $0=$ simple; $1=$ compound; $2=$ unifoliolate.

25. Phyllotaxy: $0=$ alternate; $1=$ opposite.

26. Epidermal mucilage: $0=$ present; $l=$ absent.

27. Epidermal cells: $0=$ undivided; $1=$ chambered.

28. Epidermal anticlinal walls: $0=$ straight; $1=$ undulate.

29. Stomatal pattern: $0=$ paracytic or brachyparacytic; $1=$ anomocytic; 2 = anisocytic.

30. Subsidiary cell anticlinal wall (nearest stomatal pore): $0=$ straight; $l=$ crenulate.

31. Phloem fibers of primary vein: $0=$ lignified; $1=$ thick-walled and unlignified; 2 = thin-walled and unlignified.

32. Crystals in mesophyll: $0=$ present; $1=$ absent.

33. Bundle sheath extension: $0=$ absent; $l=$ present.

34. Bundle sheath extension crystals: $0=$ absent; $1=$ prismatic.
TABle 2. Continued.

35. Venation: $0=$ brochidodromous; $1=$ irregularly brochidodromous.

36. Venation: $0=$ irregularly brochidodromous; $1=$ kladodromous.

37. Venation: $0=$ all others; $1=$ reticulodromous or hyphodromous.

38. Intramarginal vein: $0=$ absent; $1=$ present.

39. Marginal ultimate venation: $0=$ looped or incomplete; 1 = fimbriate.

40. Tertiary venation: $0=$ irregular; $1=$ orthogonal.

41. Vein order beyond tertiaries: $0=$ distinguishable; 1 $=$ indistinguishable in reticulum.

42. Areoles: $0=$ imperfect or incomplete; $1=$ well developed.

43. Tracheoid idioblasts: $0=$ absent; $l=$ present.

44. Columnar foliar sclereids: $0=$ absent; $l=$ present.

45. Stipules: $0=$ present; $1=$ absent.

46. Stipules: $0=$ on stem; $1=$ epipetiolar.

47. Raphides: $0=$ absent; $1=$ present.

48. Sexuality: $0=$ dioecious; $1=$ monoecious.

49. Petals: $0=$ present; $l=$ absent.

50. Ovules/locule: $0=$ two; $l=$ one.

51. Caruncle on seeds: $0=$ absent; $1=$ present.

52. Endosperm: $0=$ abundant; $l=$ scanty or absent.

or possibly dizonoporate, with 14-18 inconspicuous, variably shaped apertures covered with granular or smooth membranes. Punt (1962), who studied different material, considered the pollen inaperturate. All these authors used only LM. Dahlgren \& van Wyk (1988) used both LM and SEM to investigate yet another sample and found that most grains were inaperturate but some had a few places where the thin tectum apparently was torn to form a small "pore" with a granular membrane.

We examined pollen of both Androstachys and Stachyandra (= Androstachys subg. Archandrostachys Leroy), which is clearly closely related to Androstachys but has more primitive leaf morphology and flowers (Leroy, 1976; Dahlgren \& van Wyk, 1988; RadcliffeSmith, 1990). Our SEM observations indicate that all pollen in our sample of Androstachys johnsonii is pantoporate, usually with 5-7 apertures (Figs. 7, 8). With LM these apertures were often extremely inconspicuous, but could be resolved using Herr's clearing fluid (Herr, 1971). Stachyandra, in contrast, has pores easily seen with LM. Both species we examined were zoni-aperturate, $S$. merana with 4-6 pores and $S$. rufibarbis with 5-7 pores.

Erdtman (1952: 170), studying what he 

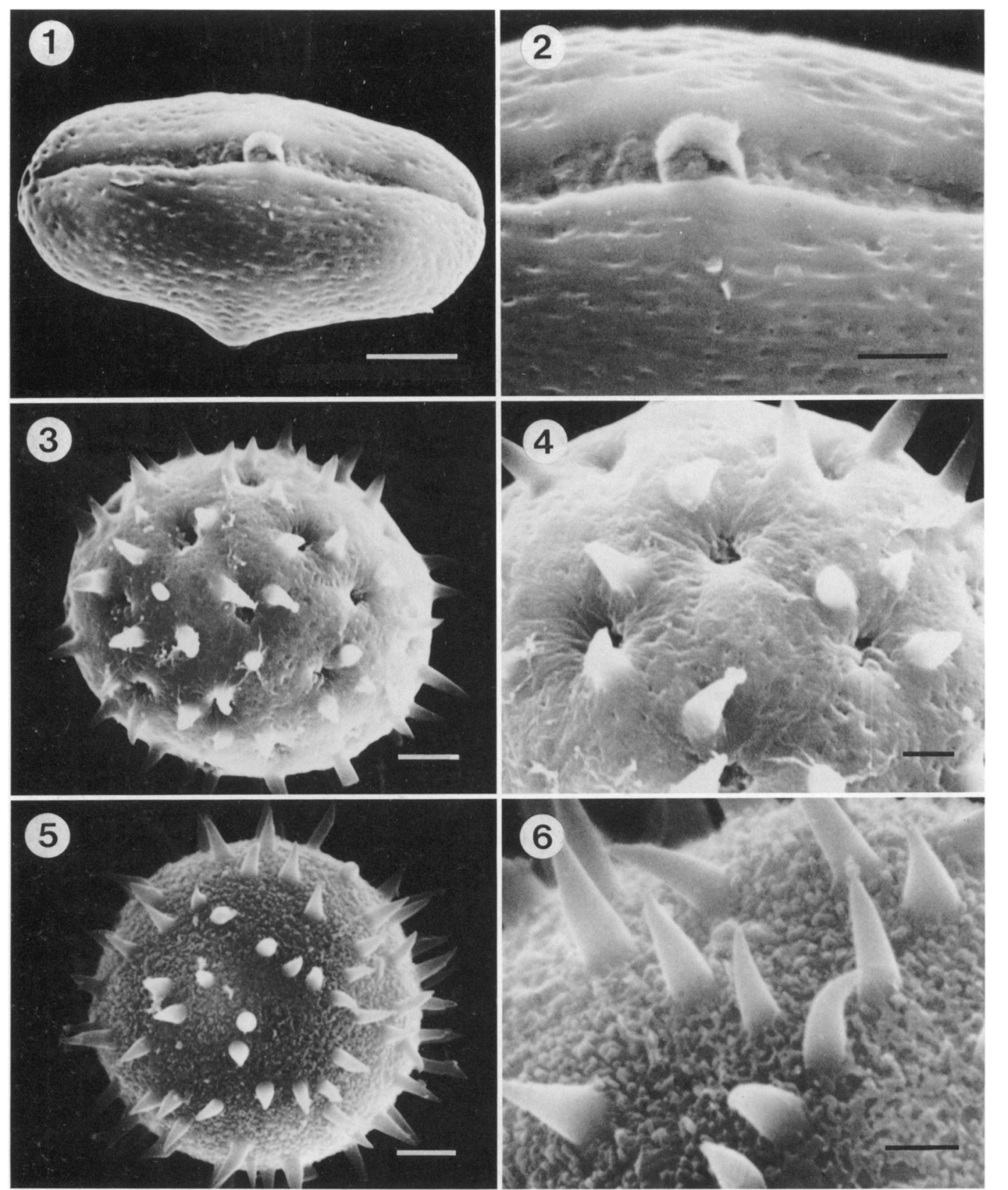

FIGURES 1-6. Scanning electron micrographs of pollen of Euphorbiaceae subfamily Phyllanthoideae $(1,2)$ and subfamily Oldfieldioideae (3-6). - 1, 2. Hyeronima alchorneoides. -3, 4. Neoroepera buxifolia. -5, 6. Parodiodendron marginivillosum. Scale bars in $1,3,5=5 \mu \mathrm{m}$; in $2,4,6=2 \mu \mathrm{m}$.

called Petalostigma pubescens, and Punt (1962) and Köhler (1965), studying what they called $P$. quadriloculare, reported that the apertures of Petalostigma do not lie exactly in the equatorial plane. Our observations are not entirely consistent with theirs. In $P . p u$ - bescens we found that some of the apertures indeed lay outside the equatorial plane, but in $P$. quadriloculare all the apertures were strictly equatorial. Prior to Airy Shaw's revision of the genus in 1976, many collections were misidentified (Airy Shaw, 1976). All of 

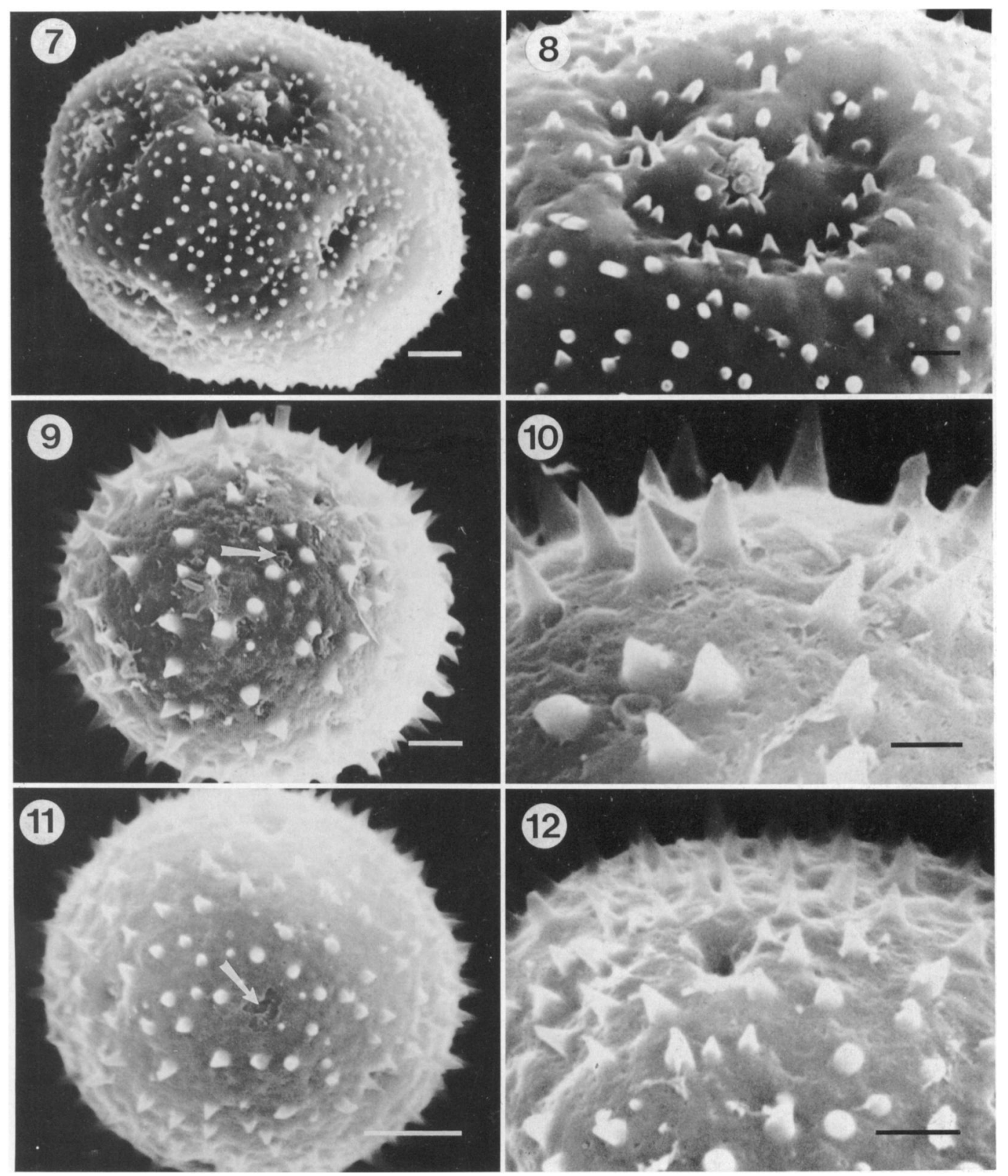

Figures 7-12. Scanning electron micrographs of pollen of Euphorbiaceae subfamily Oldfieldioideae. - 7, 8. Androstachys johnsonii. -9, 10. Micrantheum hexandrum.-11, 12. Pseudanthus divaricatissimus. Arrow in Figure 11 indicates an aperture. Scale bars in $7,9,11=5 \mu \mathrm{m}$; in $8,10,12=2 \mu \mathrm{m}$.

our samples came from specimens at Kew annotated by Airy Shaw. Unfortunately, he did not cite any of the material studied by the other palynologists, so we cannot determine if differences in observations reflect variation within species or simply misidentifications. We have therefore tentatively coded the pollen of Petalostigma as zoni-aperturate. It is possible, however, that the aperture distribution in Petalostigma may represent a transition between zoni-aperturate and pan-aperturate, particularly if the species themselves are polymorphic.

Among the species we sampled, except for Androstachys, taxa with 4-7 apertures are zoni-aperturate or essentially so, whereas those 
with 10 or more apertures are all pan-aperturate (see Table 1). A literature review, summarized in Simpson \& Levin (in prep.), shows this pattern to be generally true, the sole exception we are aware of being some species of Pseudanthus, which are pan-aperturate with 6-8 apertures.

4. Aperture shape. Apertures were either elongate and colporate (e.g., Hyeronima, Figs. 1, 2) or considerably shorter, intergrading from brevicolporate to pororate to porate (e.g., Neoroepera, Figs. 3, 4; Pseudanthus, Figs. 11, 12).

We divided exine wall sculpturing into the following two characters:

5. Sculpturing (spinal). Radially elongate, mostly sharply tapering spines are absent from some investigated Euphorbiaceae (e.g., Hyeronima, Figs. 1, 2). However, a number of taxa possess spines, the length of which ranges from relatively long (e.g., Parodiodendron, Figs. 5, 6) to short (e.g., Androstachys, Figs. 7, 8). Because we found a clear discontinuity between short tectal spines $(<0.5 \mu \mathrm{m}$ long, called "scabrae" by Reitsma, 1970) and spines of greater length $(>0.9 \mu \mathrm{m}$, called "echinae" by Reitsma), we coded these as separate states (see Table 1).

6. Sculpturing (nonspinal). This character denotes the sculpturing of the outer exine surface between spines (if present) or the general surface sculpturing if spines are not present. Reticulate pollen has a perforate tectum in which a network of muri could be delimited, regardless of the relative size of the perforations (e.g., Hyeronima, Figs. 1, 2). Foveolate pollen also has a perforate tectum but with no clear indication of tectal muri (see Croizatia, Webster et al., 1987: figs. 2, 3). In recognizing both states we differentiated between micropores, tiny perforations in the tectum present in most pollen, and the considerably larger perforations found in reticulate and foveolate pollen. Rugulate pollen has a tectum that appears conspicuously wrinkled or folded; a regular pattern of perforations is lacking (see Hymenocardia and Didymocistus, figs. 1-6 in Levin \& Simpson, 1994, this issue). The remaining states lack large perforations, though they may be microperforate. Verrucate pollen has the tectal surface covered with small rounded processes, or verrucae (see Tetracoccus, Webster et al., 1987: fig. 5). Some taxa were coded "?" because we were unable to determine from the micrographs whether the pollen was verrucate or foveolate. The sculpturing of Picrodendron might be termed "vermiform" in that the tectal processes are somewhat elongated and twisted, but we coded it as verrucate because of its basic similarity to that pattern and because the sculpturing of Parodiodendron (Fig. 6) is somewhat transitional. Psilate-wrinkled pollen has a relatively smooth tectum apparently devoid of (nonspinal) sculpturing (e.g., Androstachys, Fig. 8), or may appear somewhat wrinkled, perhaps a function of specimen preparation.

We treated the structure of the exine wall as four separate characters $(7-10)$. The first three correspond to the three general regions of the ektexine between the apertures.

7. Foot-layer. Several taxa have a typical continuous, homogeneous ektexinous foot-layer (e.g., Antidesma, Fig. 13; Amanoa, Figs. 14, 15; Croizatia, Fig. 16). Analysis of the variation in foot-layer thickness within and among these taxa (Fig. 17) shows four distinct size classes that could be validly recognized as character states (Stevens, 1991). In preliminary cladistic analyses we tried dividing this character into four states, lumping the two largest size classes into a single state, or combining all but the smallest size class into a single state. Because the resulting trees were the same in all three cases and so few taxa fell into the two largest size classes, we decided to recognize only two states $(<0.5 \mu \mathrm{m}$ and $>0.5 \mu \mathrm{m}$ ) for the homogeneous foot-layer.

In the remaining taxa, the ektexinous footlayer was very irregular, consisting of discontinuous, almost granular elements (Figs. 1823). At one extreme (e.g., Tetracoccus, Fig. 19), this irregular foot-layer was present around the entire grain; at the other extreme (e.g., Oldfieldia, Fig. 18), the ektexinous footlayer was essentially absent, represented only by rare and scattered granules. Various intermediates were present (e.g., Longetia, Fig. 23), preventing us from distinguishing the two extremes as separate states. The innermost layer of ektexine in both Podocalyx (Fig. 20) and Paradrypetes (Fig. 21) we interpreted as an irregular foot-layer (see character \#8, below).

Endexine was found as a thin to moderately thick basal layer (usually thickening at the 

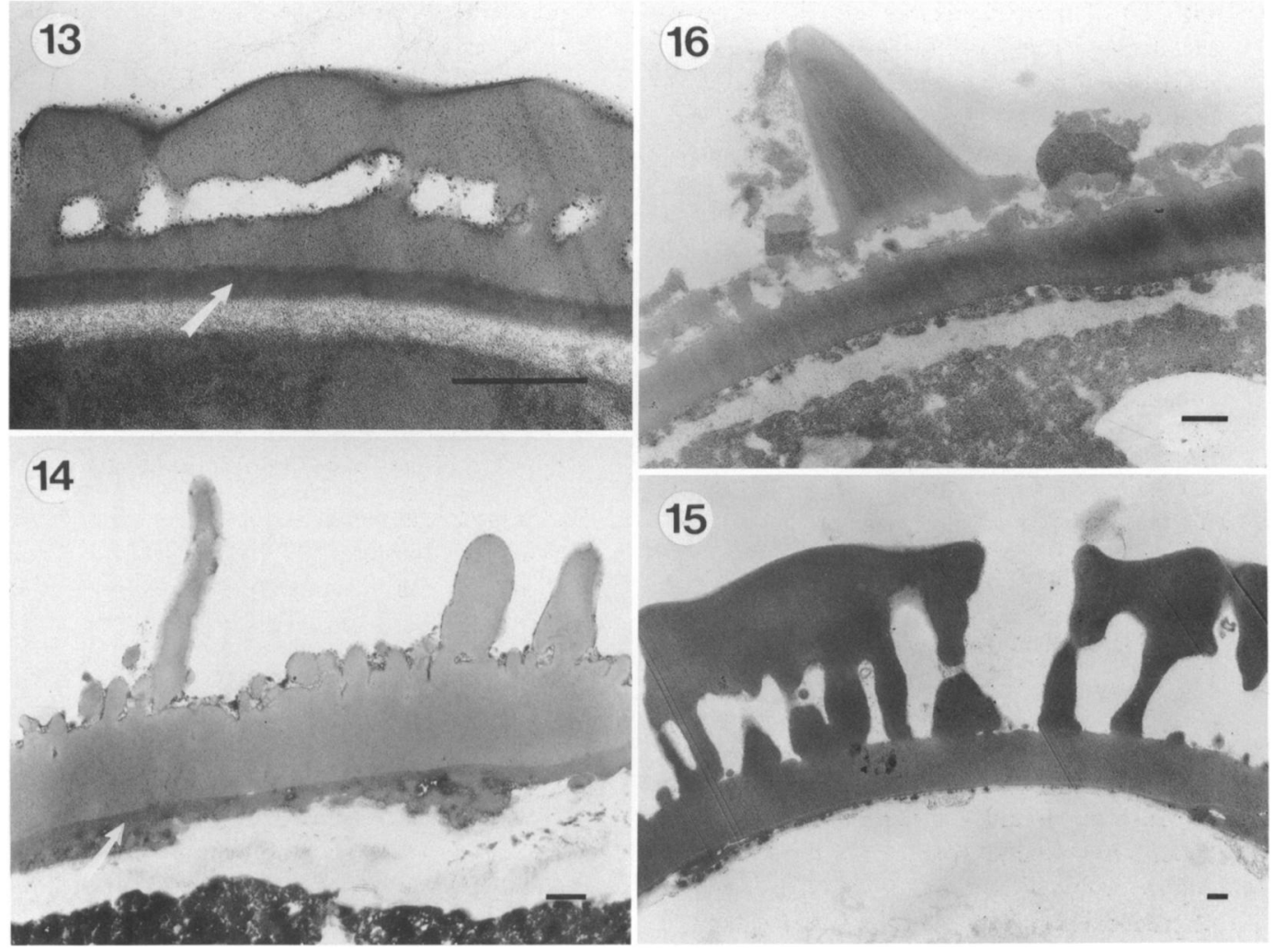

FigurEs 13-16. Transmission electron micrographs of pollen of Euphorbiaceae subfamily Phyllanthoideae (1315) and subfamily Oldfieldioideae (16). - 13. Antidesma membranaceum. - 14. Amanoa guianensis. - 15. Amanoa strobilacea. - 16. Croizatia naiguatensis. Arrow in Figure 13 indicates endexine. Scale bars $=0.5 \mu \mathrm{m}$.

aperture periphery) in almost all taxa (see Antidesma, Fig. 13; Oldfieldia, Fig. 19) and does not seem to be of taxonomic significance.

8. Interstitium. The interstitium may consist of columellae that are continuous with the footlayer, as in the typical "tectate-columellate" architecture (e.g., Antidesma, Fig. 13; Amanoa strobilacea, Fig. 15), or an evident discontinuity may occur between the columellar elements and foot-layer (e.g., Tetracoccus, Fig. 19; Scagea, Fig. 24; Stachystemon, Fig. 25). In no case did the columellae appear to be discontinuous with the tectal region. Thus, in taxa such as Podocalyx (Fig. 20) and Paradrypetes (Fig. 21), in which the exine consists of a relatively thick outer layer discontinuous from a thin, granular inner layer, we interpreted the inner layer as an irregular footlayer and the interstitium as absent.

9. Tectum. Two variables affect tectum structure: its degree of perforation and its organization. The tectum of some taxa (e.g., $A n$ - tidesma, Fig. 13; Amanoa strobilacea, Fig. 15) is homogeneous and penetrated by large perforations rather than microperforations, a state we called "perforate/homogeneous." (Because of the large size of the perforations, they may be absent in some TEM sections making the tectum appear imperforate.) Among taxa with a microperforate tectum, three states were apparent. The tectum may be "microperforate/homogeneous" (e.g., Androstachys, Fig. 22); "microperforate/baculate," consisting of numerous closely appressed rod-shaped elements, some of which are continuous with the columellae and/or echinae (e.g., Oldfieldia, Fig. 18; Tetracoccus, Fig. 19); or "microperforate/granular," consisting of small, irregular, globular to tabular elements (e.g., Croizatia, Fig. 16; Scagea, Fig. 24; Stachystemon, Fig. 25). Still other taxa have a tectum that is "imperforate," lacking both perforations and microperforations (e.g., Paradrypetes, Fig. 21; 


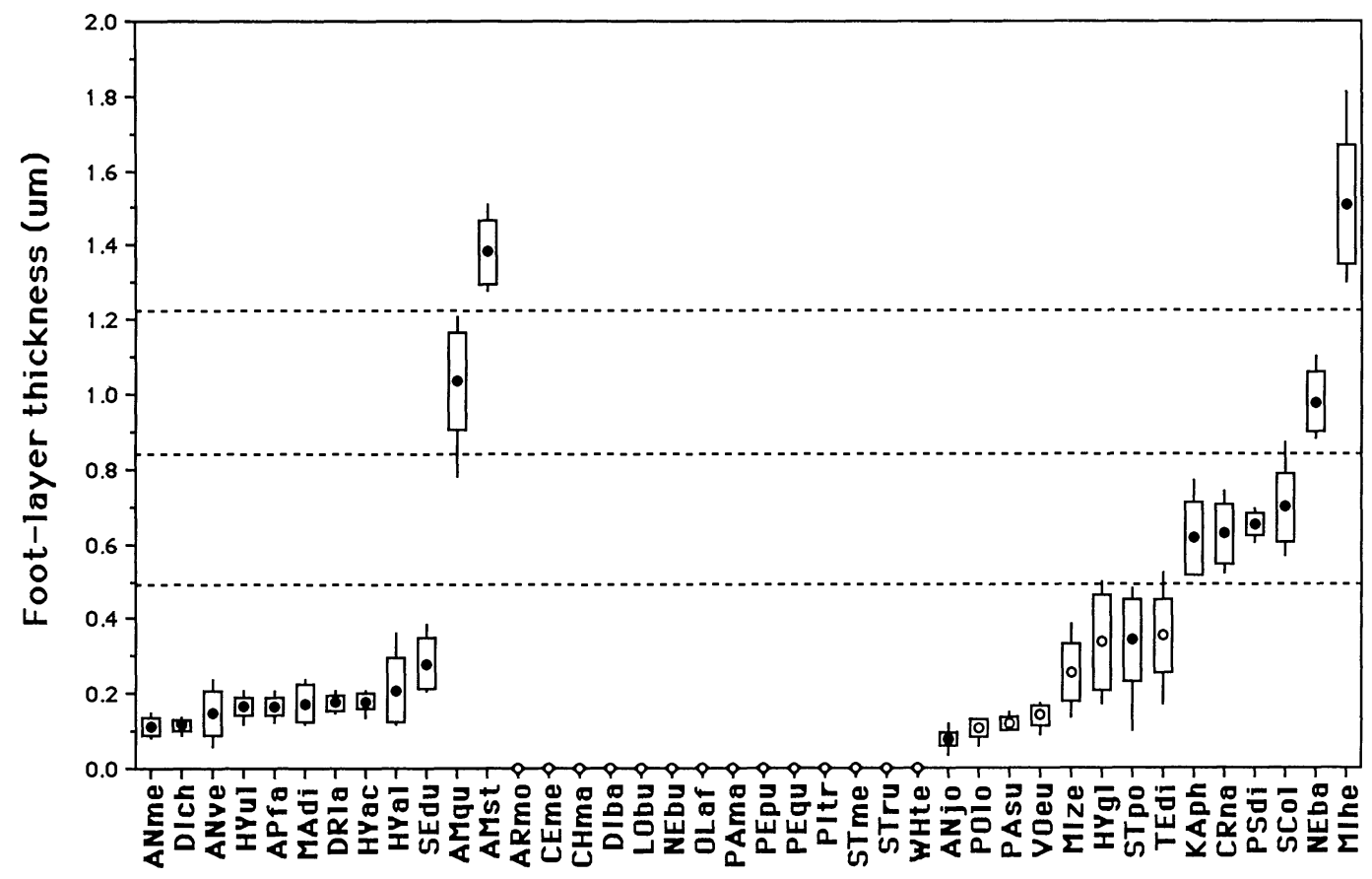

Taxa

Figure 17. Distribution of pollen exine foot-layer thickness among sampled species of Euphorbiaceae. A circle (solid for species with the foot-layer homogeneous and open for species with the foot-layer irregular or absent) indicates the mean thickness, a vertical bar the range, and a rectangle two standard deviations on either side of the mean (N $=$ minimum of 10 measurements from one to three grains). Species are arranged by increasing thickness within a subfamily, with the Phyllanthoideae on the left and the Oldfieldioideae on the right. Dashed lines separate size-classes that we considered potential character states. Abbreviations for species names: AMgu = Amanoa guianensis, AMst $=$ Amanoa strobilacea , ANjo = Androstachys johnsonii, $\mathrm{ANme}=$ Antidesma membranaceum, $\mathrm{ANve}=$ Antidesma venosa, $\mathrm{APfa}=$ Aporusa falcifera, $\mathrm{ARmo}=$ Aristogeitonia monophylla, CEme $=$ Celaenodendron mexicanum, $\mathrm{CHma}=$ Choriceras majus, $\mathrm{CRna}=$ Croizatia naiguatensis, DIba $=$ Dissiliaria baloghioides, DIch $=$ Didymocistus chrysadenius, $\mathrm{DRla}=$ Drypetes lateriflora, $\mathrm{HYac}=$ Hymenocardia acida, $\mathrm{HYal}=$ Hyeronima alchorneoides, $\mathrm{HYgl}=$ Hyaenanche globosa, $\mathrm{HYul}=$ Hymenocardia ulmoides, $\mathrm{KAph}=$ Kairothamnus phyllanthoides, LObu = Longetia buxoides, MAdi = Margaritaria discoidea, MIhe = Micrantheum hexandrum, MIze = Mischodon zeylanicus, $\mathrm{NEba}=$ Neoroepera banksii, $\mathrm{NEbu}=$ Neoroepera buxifolia, OLaf $=$ Oldfieldia africana, PAma $=$ Parodiodendron marginivillosum, PAsu = Paradrypetes subintegrifolia, $\mathrm{PEpu}=$ Petalostigma pubescens, $\mathrm{PEqu}$ $=$ Petalostigma quadriloculare, $\mathrm{PItr}=$ Piranhea trifoliata, POlo $=$ Podocalyx loranthoides, FSdi $=$ Pseudanthus divaricatissimus, $\mathrm{SCol}=$ Scagea oligostemon, $\mathrm{SEdu}=$ Securinega durissima, $\mathrm{STme}=$ Stachyandra merana, $\mathrm{STpo}$ = Stachystemon polyandrus, STru = Stachyandra rufibarbis, TEdi = Tetracoccus dioicus, VOeu = Voatamalo eugenioides, WHte = Whyanbeelia terrae-reginae

Longetia, Fig. 23). Finally, we interpreted the exine of Amanoa guianensis (Fig. 14) as lacking a tectum; the echinae of this taxon we believe to be homologous to columellae. Evidence for this interpretation is the different structure of these echinae (distally rounded, unlike all other investigated taxa, which have sharply pointed echinae) and the probable homology of the echinae of Amanoa guianensis with the columellae of the related Amanoa strobilacea (Fig. 15).

Tectum thickness varied considerably among the taxa we examined (Fig. 26). The variation was almost continuous, however, with the only supportable breaks associated with single taxa and therefore leading to phylogenetically uninformative autapomorphies if coded as separate states. We therefore did not use tectum thickness as a character.

10. Ektexinous periapertural thickenings. The pollen of most of the taxa we examined had much thicker exine around the apertures than in the nonapertural regions. In most cases these thickenings were formed by the endexine, but in a few genera the thickenings were formed by the ektexine; in no cases did we observe both endexinous and ektexinous thickenings. Occasional taxa had no apparent thick- 


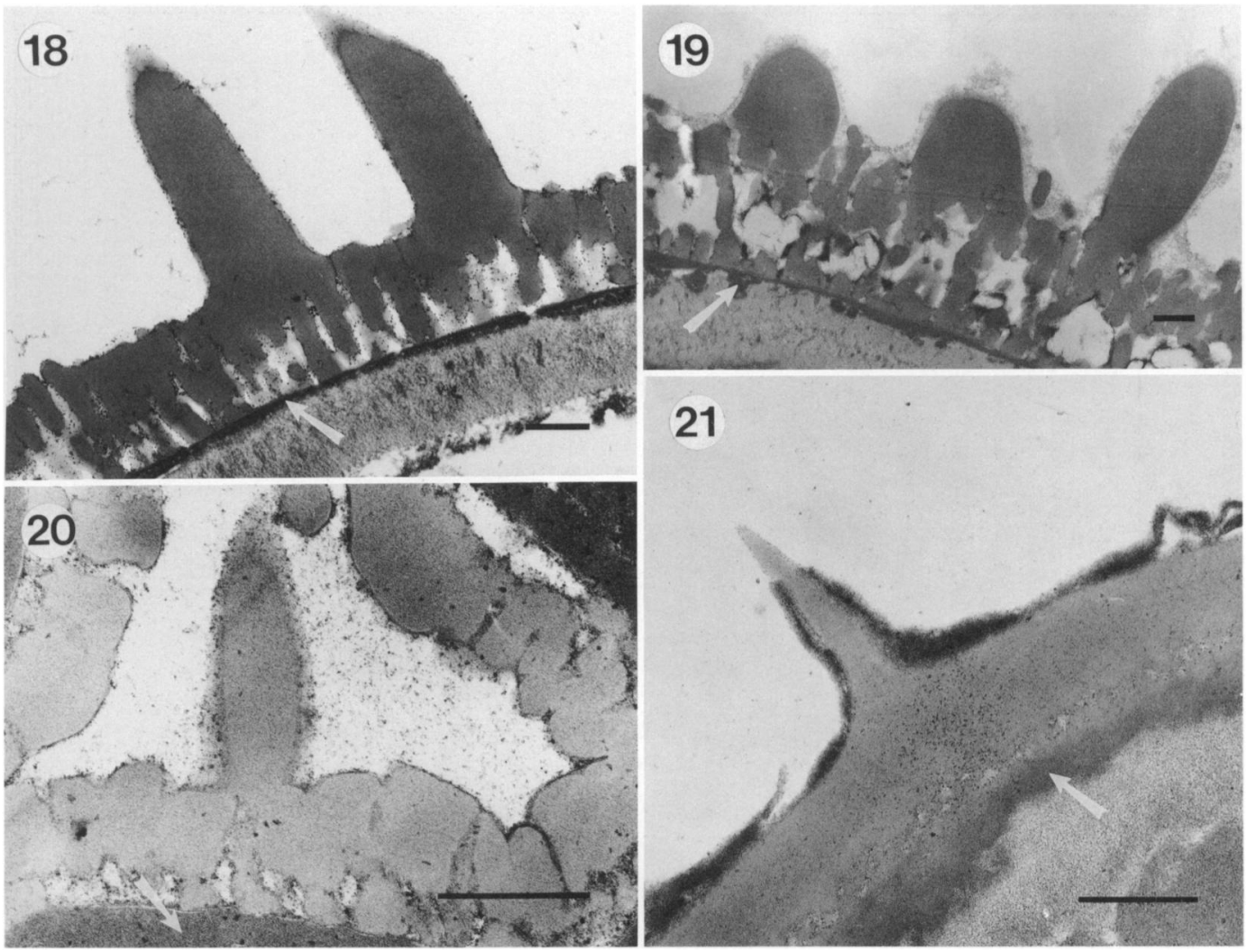

FIGURES 18-21. Transmission electron micrographs of pollen of Euphorbiaceae subfamily Oldfieldioideae. - 18. Oldfieldia africana. - 19. Tetracoccus dioicus. - 20. Podocalyx loranthoides. -21. Paradrypetes subintegrifolia. Arrows indicate endexine. Scale bars $=0.5 \mu \mathrm{m}$.

enings, though in several of these the endexine became more electron-dense around the apertures. Because preliminary analysis showed that the presence or absence of endexinous thickenings had little phylogenetic significance, we have included only ektexinous thickenings in this analysis.

Alternative codings. Though the way in which we have coded the pollen characters may appear to permit them to vary independently, the pattern of variation within the taxa combined with the coding predisposes certain outcomes. This problem, and our attempt to address it, can be most easily demonstrated with the characters for aperture number and distribution. As we have coded these characters, a group potentially supported by the pan-aperturate condition is nested within a group potentially defined by aperture number greater than three; the group with more than three zonate apertures is necessarily paraphyletic based on these characters alone. This is because all taxa with panaperturate pollen, the derived state of one char- acter, have more than three apertures, the derived state of another character. Combining these two characters into a single, unordered character with three states - zonate with three apertures, zonate with more than three apertures, and pan-aperturate-allows the group with more than three zonate apertures to be potentially monophyletic based on this single pollen character. We tried recoding these characters and found that both codings gave the same cladograms.

Similar considerations apply to pollen shape and aperture type, pollen shape and aperture number, and nonspinal sculpture and tectum structure, and perhaps others. As with the example we discussed above, combining a pair of characters into a one unordered multistate character did not affect the results of our phylogenetic analysis. We have therefore chosen to present the data as we have, which we consider simpler and more informative.

Vegetative morphology and anatomy. Most of the wood and leaf characters (11-47) that we included in our analysis are discussed by Hayden 

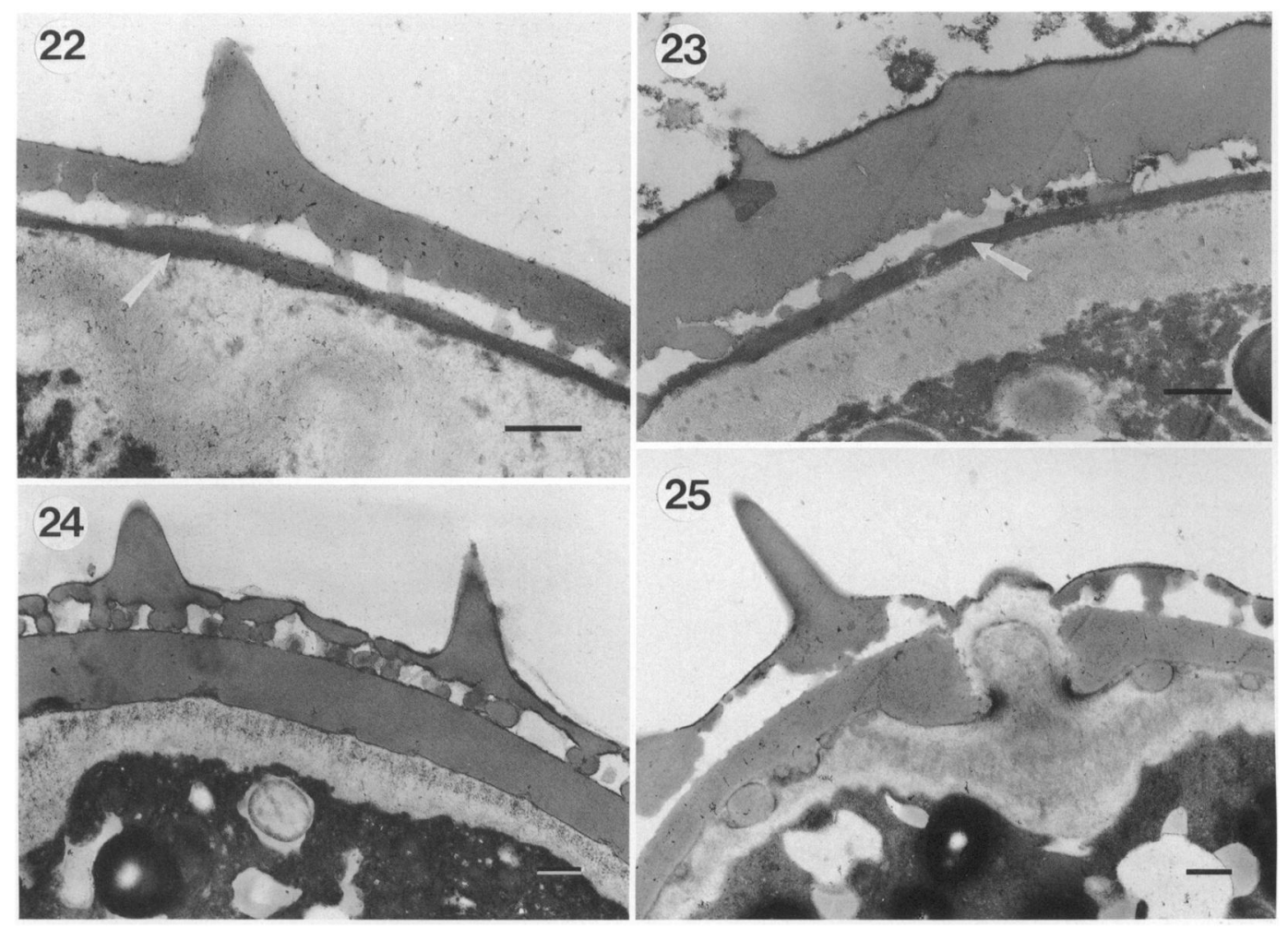

FigurEs 22-25. Transmission electron micrographs of pollen of Euphorbiaceae subfamily Oldfieldioideae. - 22. Androstachys johnsonii.-23. Longetia buxoides. -24. Scagea oligostemon.-25. Stachystemon polyandrus. Arrow in Figure 23 indicates endexine. Scale bars $=0.5 \mu \mathrm{m}$.

(1994, this issue). We obtained data for the Oldfieldioideae from his paper, and data for genera in Phyllanthoideae and the uniovulate subfamilies of Euphorbiaceae from Hayden (1980), Levin (1986a), Matos Araujo \& Mattos Filho (1984), Mennega (1984, 1987), Metcalfe \& Chalk (1950), Milanez (1935), and miscellaneous monographs cited below. In most cases, we could code characters directly from Hayden (1994). Following is a discussion of those characters he did not include or for which our interpretation may differ from Hayden's.

12. Perforation plates. Rather than distinguishing exclusively scalariform from mixed simple and scalariform, we combined these conditions into one state. Had we treated them as separate states, polarizing the character would have been difficult because both conditions are found within some of the genera of Phyllanthoideae we included as outgroups.

19. Crystalliferous ray cells. Many genera have ray cells containing one or occasionally several crystals. In most of these genera, as far as we can gather from the literature (e.g., Hayden, 1980, 1994; Milanez, 1935; Matos Araujo \& Mattos Filho, 1984), the crystalliferous cells are unsclerified. In Aristogeitonia, Mischodon, Voatamalo, and the alternate-leaved species of Tetracoccus, however, the crystalliferous ray cells are sclerified. Unfortunately, ambiguities in the literature regarding wood anatomy of the Phyllanthoideae prevent us from being entirely confident about the condition of some of our outgroup genera.

20. Axial xylem parenchyma. Axial xylem parenchyma is uniformly present in the Oldfieldioideae, though its distribution varies to some extent. Only limited data on the distribution of axial 'xylem parenchyma are available for the 'Phyllanthoideae, so we were able only to record its presence or absence. Despite this extreme simplification, we included this character because it helps resolve relationships among 


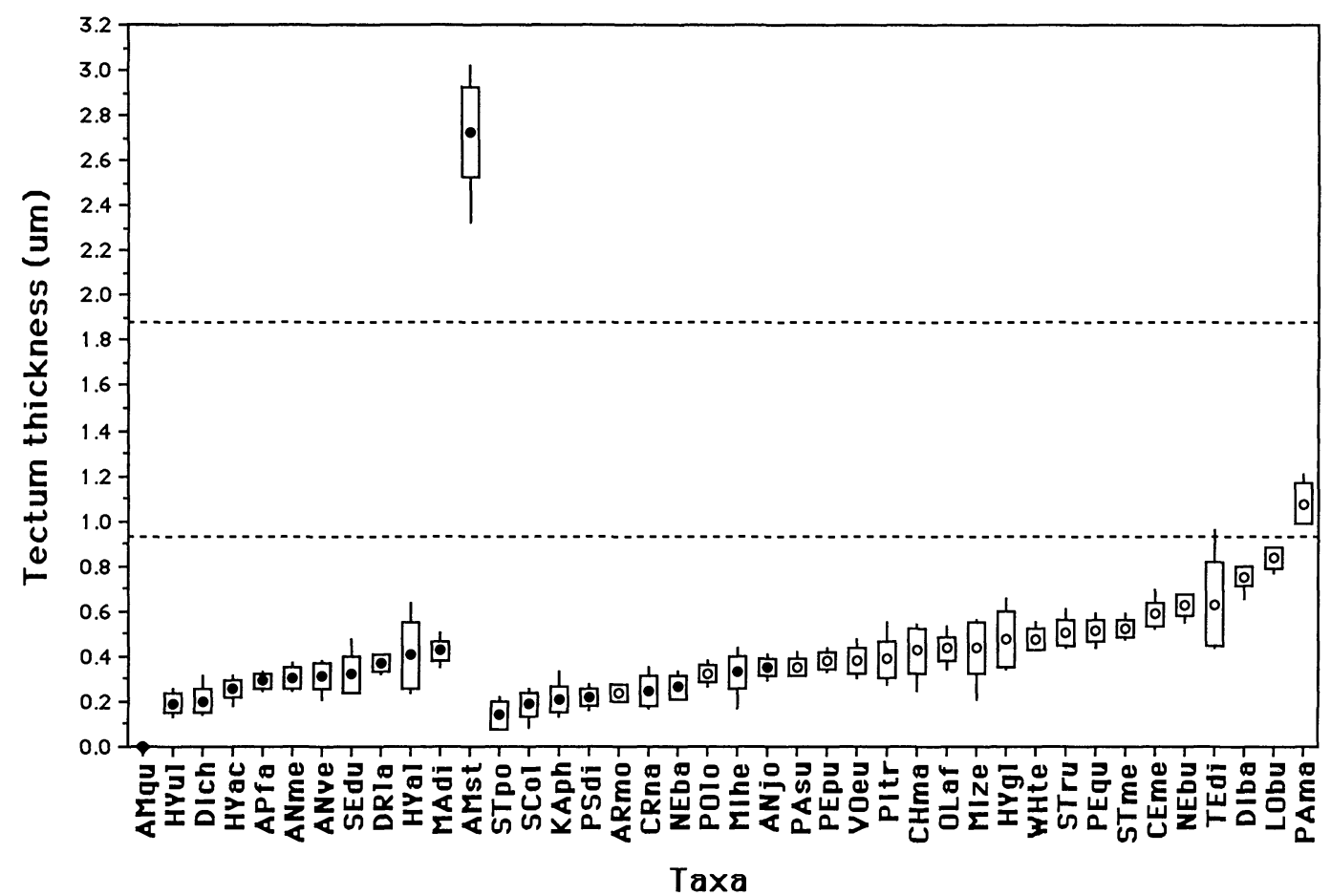

Figure 26. Distribution of pollen tectum thickness among sampled Euphorbiaceae. Format and abbreviations are the same as in Figure 17.

the taxa we included as outgroups for the Oldfieldioideae.

24. Leaf blade. We tried treating this character both as an unordered character and as an ordered character arranged simple to compound to unifoliolate. In our experience with other groups, unifoliolate leaves appear to be reductions from compound leaves rather than to have evolved directly from simple leaves. With this data set, we found that it is more parsimonious to derive unifoliolate leaves from compound leaves, regardless of whether the character is ordered or unordered. We coded Micrantheum, interpreted as having either sessile compound leaves or simple leaves with foliate stipules (Hayden, 1994), as equivocal ("?") for this character.

25. Phyllotaxy. We coded opposite and whorled as the same state because at least some species, e.g., Tetracoccus dioicus, bear both opposite and whorled leaves. Two genera, Tetracoccus and Oldfieldia, have some species with alternate leaves and others with opposite or whorled leaves. Because the phylogeny of species within these genera is not well understood, we coded these taxa as polymorphic for this character.

29. Stomatal pattern. Because Phyllanthoideae have both paracytic and brachyparacytic stomata, sometimes on the same leaf (Levin 1986a), we treated these as the same state. Though the only other stomatal pattern in Oldfieldioideae is anomocytic, Aporusa, one of the outgroup genera, has anisocytic stomata. We did not differentiate between undivided and subdivided subsidiary cells because this may vary within a single leaf (Hayden, 1994).

31. Phloem fibers of primary vein. In most genera the phloem fibers in the primary vein have thick lignified walls. In $M i$ crantheum, Neoroepera banksii, Pseudanthus, and Stachystemon, the fibers are similarly thick-walled but unlignified. The phloem fibers of Petalostigma are also unlignified but have thin walls (W. J. Hayden, pers. comm.). Because of the difference in wall thickness, we were not sure a priori that the unlignified condition was homologous in these five taxa. We 


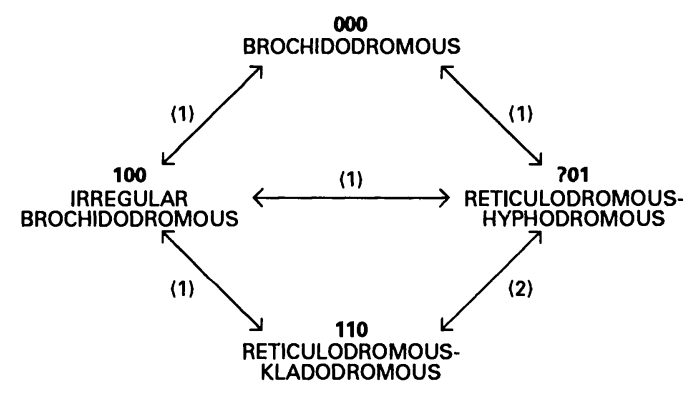

FIGURE 27. Character coding for leaf venation, characters $35-37$.

therefore recognized three unordered states for the phloem fibers: lignified, thickwalled and unlignified, and thin-walled and unlignified.

34. Bundle sheath extension crystals. Some genera have no bundle sheath extensions (character 33 , state 0 ). We coded these genera as equivocal ("?") for character 34.

35-37. Venation. Four basic leaf venation patterns occur in Oldfieldioideae (Hayden, $1980,1994)$. In most genera venation is brochidodromous (coded 000 for these characters; terminology follows Hickey, 1979), but considerably less organized venation is found in four genera. The venation of Micrantheum forms a highly irregular brochidodromous pattern, which we coded "100." More irregular still is the reticulodromous to kladodromous venation of Stachystemon and Pseudanthus. Because the reticulodromous pattern in some Stachystemon species appears somewhat like the venation pattern in Micrantheum, we interpret irregular brochidodromous venation as evolutionarily intermediate to reticulodromous to kladodromous venation, and code the condition in Stachystemon and Pseudanthus "110." Finally, Tetracoccus leaves have reticulodromous to hyphodromous venation. It was not clear a priori whether this pattern evolved from irregular brochidodromous venation like that of Micrantheum or if it evolved independently from a brochidodromous pattern, but it probably did not evolve from kladodromy. To allow the two likely possibilities to be equally parsimonious a priori, we coded reticulodromous to hyphodromous venation "?01." See Figure 27 for a diagram of our proposed leaf venation transformation series and its coding.

45-46. Stipules. McPherson \& Tirel (1987) stated that the stipules of Austrobuxus and Longetia are extremely reduced to absent. The same may be true of other Dissiliariinae sensu Webster (1994), but we cannot find specific reference to the stipules in the other genera in the subtribe and have therefore coded these genera as equivocal ("?"). When describing Whyanbeelia, Airy Shaw \& Hyland (in Airy Shaw, 1976) stated "stipulae haud certe visae, forsan obsoletae" (stipules not certainly seen, perhaps obsolete). One of us (Levin) examined a paratype of $W$. terrae-reginae (Hyland 3041, DAV) and was unable to find evidence of stipules. We have therefore tentatively coded Whyanbeelia as lacking stipules (see further discussion in section on taxonomic implications). We coded Micrantheum as equivocal ("?") for this character; see the discussion of character 24 above.

In addition to stipule size, stipule position appeared phylogenetically significant. Stipules may arise from the stem or be epipetiolar, i.e., arise from the petiole.

47. Raphides. Paradrypetes is unique among Oldfieldioideae, and apparently Euphorbiaceae, in having raphides (Milanez, 1935; Matos Araujo \& Mattos Filho, 1984; Levin, 1986a). All other Euphorbiaceae with crystals have druses and/or prismatic crystals.

Reproductive morphology. For completeness we tried to include some characters of reproductive morphology in our phylogenetic analysis. Unfortunately we have been completely dependent on published descriptions for genera other than Paradrypetes. Literature reports on reproductive morphology of Oldfieldioideae are incomplete and often difficult to interpret because different authors have used descriptive terms inconsistently. For example, floral discs in some genera are described as "fused glands" whereas in others they may be described as "lobed." Without first-hand experience with the flowers, we cannot tell whether discs in these genera are actually different or merely described differently. Inflorescence architecture is similarly difficult to interpret. When we restricted our list to those characters we felt we could interpret with reasonable confidence, only five characters (4852 ) remained. We expect that a careful study of 
oldfieldioid reproductive morphology will yield significant characters beyond those in our meager list.

Following is a discussion of each of the reproductive characters we included. We obtained most of our data on reproductive morphology from Pax \& Hoffmann (1922, 1931), Bosser (1976), Airy Shaw (1972, 1974, 1976, 1980), and McPherson \& Tirel (1987).

48. Sexuality. Plants may be either monoecious or dioecious. The literature was unambiguous regarding the character state in each genus except Aristogeitonia. Pax \& Hoffmann (1931) described this genus as monoecious, but both Airy Shaw (1972) and RadcliffeSmith (1987b) reported it to be dioecious. We have followed the more recent authors who worked with far more specimens.

49. Petals. Though petals are uniformly absent in the Oldfieldioideae, we included this character to help resolve relationships among the outgroup taxa.

50. Ovules/locule. Since Jussieu (1824) first recognized its importance, ovule number has been regarded as one of the principal taxonomic characters in Euphorbiaceae. Phyllanthoideae and Oldfieldioideae bear two ovules/locule, whereas the remaining Euphorbiaceae bear one ovule/locule. Scagea, however, is uniovulate (McPherson, 1985; McPherson \& Tirel, 1987) yet has pollen like that of some Oldfieldioideae (Simpson \& Levin, in prep.; see also the cladistic analysis below).

51. Caruncle on seeds. Most Oldfieldioideae have carunculate seeds. Apparent exceptions are Androstachys (Dahlgren \& van Wyk, 1988), Aristogeitonia (Pax \& Hoffmann, 1922; Radcliffe-Smith, 1987a), Celaenodendron (Standley, 1927), Kairothamnus (Airy Shaw, 1974, 1980), and Picrodendron (Hayden, 1977; Hayden et al., 1984). We were unable to find data on Neoroepera, Podocalyx, Voatamalo, and Whyanbeelia.

52. Endosperm. With the exception of Hyaenanche (Pax \& Hoffmann, 1922) and Picrodendron (Hayden, 1977; Hayden et al., 1984), Oldfieldioideae have seeds with abundant endosperm. We were unable to obtain data on Kairothamnus, Voatamalo, and Whyanbeelia.

\section{CHARACTER POLARIZATION}

Phylogenetic analysis of the primitive Euphorbiaceae is complicated by the absence of a clear consensus regarding the relationships of the family (see review by Webster, 1987) and therefore which taxa should be chosen as outgroups to polarize the characters. Taxa that have been proposed in recent years include Flacourtiaceae (Hickey \& Wolfe, 1975; Levin, 1986a, c), Celastrales (Cronquist, 1981), Linales (Webster, 1987), and Malvales, particularly Elaeocarpaceae and Sterculiaceae (Takhtajan, 1980; Dahlgren, 1983; Thorne, 1983). In the absence of a well-accepted outgroup, particularly when the potential outgroups appear not to be closely related to each other, as is clearly the case here, the best approach may be the outgroup substitution method proposed by Donoghue \& Cantino (1984; see also Maddison et al., 1984). In this method, the potential outgroups are used alone and in plausibly related groups in separate phylogenetic analyses. The resulting cladograms are then examined for regions of consensus. In our analyses, we used each outgroup separately, Elaeocarpaceae plus Sterculiaceae (Malvales), Flacourtiaceae plus Elaeocarpaceae plus Sterculiaceae (Dilleniidae of Cronquist, 1981), Linales plus Flacourtiaceae (Chase et al., 1991; M. Chase, pers. comm.), and all outgroups together without any predetermined topology.

\section{CLADISTIC ANALYSIS}

Table 3 contains the character $\times$ taxon data matrix for our analyses. In order to explore the systematic implications of the pollen data we first performed cladistic analyses on these data alone. Then we performed cladistic analyses on the complete data set. In both cases both PAUP and HENNIG86 yielded numerous equally parsimonious trees, differing mainly in local rearrangement of taxa. We therefore produced a strict consensus tree for each data set. Choice of outgroup did not change the topology of the Oldfieldioideae on the consensus trees, but did affect the topology of the remaining taxa enough that a consensus among the various trees has limited resolution. Because of this and our limited sample of non-oldfieldioid taxa we will restrict most of our discussion to the relationships among Oldfieldioideae.

Pollen. Initial analysis showed that nonspinal sculpturing (character 6) was very homoplastic. Because of this and the large number of taxa for which we were unable to determine the sculpturing, we dropped this character from further analysis. The consensus tree based on the remaining pollen data alone is shown in Figure 28. We show only the Oldfieldioideae (including Croizatia, Paradrypetes, and Scagea); the tree is rooted using the 
TABLE 3. Character $\times$ taxon matrix for cladistic analysis of investigated Euphorbiaceae. All multistate characters are unordered. A "?" indicates an unknown or equivocal character state. Taxa with polymorphic characters are indicated by an " $\&$ " preceding a second line containing the alternate states for the polymorphic characters. Outgroup taxa are listed first, followed by taxa in the Euphorbiaceae. Taxa in the Phyllanthoideae are listed alphabetically, whereas taxa in the Oldfieldioideae are in the order shown in one of our preferred cladograms (Figs. 31-33A).

\begin{tabular}{|c|c|}
\hline & Characters \\
\hline Taxa & $\begin{array}{l}0000000001111111111222222222233333333334444444444555 \\
1234567890123456789012345678901234567890123456789012\end{array}$ \\
\hline \multicolumn{2}{|l|}{ Outgroups } \\
\hline Flacourtiaceae & $00000 ? ? 00 ? 0 ? ? ? ? 00 ? 010 ? ? 000 ? ? ? 00 ? 0 ? 0000 ? ? 0 ? 0000010000$ \\
\hline Celastraceae & $000000 ? ? 0 ? 0110 ? 0010 ? ? ? 00 ? 0 ? ? ? 000 ? 00000 ? ? 0 ? 000001 ? 0 ? 0$ \\
\hline Linales & 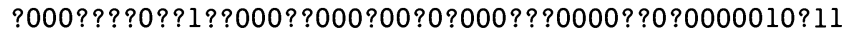 \\
\hline Elaeocarpaceae & $100000 ? ? 0 ? 00 ? 1100 ? 00 ? 000000 ? 0000 ? ? 0000 ? 10 ? 00000 ? 0000$ \\
\hline Sterculiaceae & $0 ? ? ? ? ? ? ? ? ? 0110000 ? 00000 ? 000 ? 1000 ? ? 0000 ? 10 ? 00000 ? ? 0 ? 0$ \\
\hline \multicolumn{2}{|l|}{ Euphorbiaceae } \\
\hline Acalyphoideae & 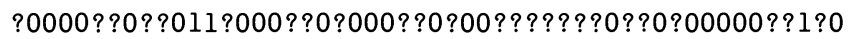 \\
\hline Crotonoideae & 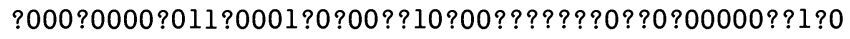 \\
\hline Euphorbioideae & 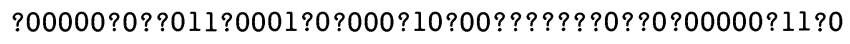 \\
\hline \multicolumn{2}{|l|}{ Phyllanthoideae } \\
\hline Amanoa strobilacea & $00000000000010000 ? 0000000 ? 0000 ? 0 ? ? 000000000000010001$ \\
\hline Amanoa guianensis & $0000 ? ? 00500010000 ? 0000000 ? 0000 ? 0 ? ? 000000000000010001$ \\
\hline Antidesma & $10000000000110100000 ? 000000100 ? 0 ? ? 000001000000001000$ \\
\hline Aporusa & $00000000000010000000 ? 000000020 ? 0 ? ? 000001000000001000$ \\
\hline Didymocistus & $000012000000 ? 0100 ? 01 ? ? 000 ? 0000 ? 0 ? ? 00000101000000100 ?$ \\
\hline Drypetes & $10000000000 ? 10000 ? 0000000 ? 010000000000 ? 10 ? 0000001000$ \\
\hline Hyeronima & $100000000000 ? 0000000 ? 000000000 ? 0 ? ? 000001000000001000$ \\
\hline Hymenocardia & $00011200010110100001 ? 000000000 ? 0 ? ? 000001010000001001$ \\
\hline Margaritaria & $100000000001 ? 0100101 ? 0000 ? 0000 ? 0 ? ? 0000 ? 1000000001000$ \\
\hline Phyllanthus & ???00000?0110100101?000000000?0??000001000000011000 \\
\hline Securinega & $00002 ? 00000110000100 ? ? 000 ? 0 ? 00 ? ? ? ? ? ? ? ? ? ? ? ? ? ? 0000100 ?$ \\
\hline \multicolumn{2}{|r|}{ - } \\
\hline Croizatia & $0001211131 ? ? ? ? ? ? ? ? ? ? ?, 000 ? 0000 ? 0 ? ? 000001000000000001$ \\
\hline Paradrypetes & $01012422400000000000100010000000 ? ? 000000000000101000$ \\
\hline Podocalyx & $01012422200001000000100001001000100000000110000010 ? 0$ \\
\hline Tetracoccus & $010123212 ? 11100001000000100000000 ? ? 010000000 ? 0001010$ \\
\hline$\&$ & 0 \\
\hline Parodiodendron & $01012321200111100100000200000001110000000100000010 ? 0$ \\
\hline Picrodendron & $010123212001110001000001 ? 000000111000010110000001001$ \\
\hline Piranhea & $010123212 ? 011100010000010101000111000011110000001010$ \\
\hline Celaenodendron & $01012 ? 21200111000100000101010001110000101100 ? 0001000$ \\
\hline Oldfieldia & $01012321200110000100000100000000100000100100 ? 0001010$ \\
\hline$\&$ & 1 \\
\hline Androstachys & 0111240010011000010000021000000010000010110101001010 \\
\hline Stachyandra & 0101242110011000010000011000000010000010110101000000 \\
\hline Voatamalo & $01012 ? 212 ? 011000011000 ? 01 ? ? ? ? ? ? ? ? ? 0000 ? ? ? ? ? ? 010010 ? ?$ \\
\hline Mischodon & $01012 ? 212 ? 011000011000001100000010000010010001001010$ \\
\hline Aristogeitonia & $01012 ? 21200110 ? 001100001010100000 ? 000010010001001000$ \\
\hline$\&$ & 2 \\
\hline Hyaenanche & $010123212001100000000000100001000 ? 000000000000001011$ \\
\hline Austrobuxus & $010121212 ? 01110000000000101001000 ? 000000000010001010$ \\
\hline Whyanbeelia & $010121212101100000001000101001000 ? 0000000000100110 ? ?$ \\
\hline Longetia & $0101142141 ? ? ? ? ? ? ? ? ? ? ?, 001010010010000000000010011010$ \\
\hline Choriceras & $010114211101100010000000101001000 ? 000000000010011010$ \\
\hline Dissiliaria & $01012 ? 212101100000000000101101001 ? 000010010010001010$ \\
\hline Petalostigma & $01012 ? 2120011000000010000010012011000000000000001010$ \\
\hline Neoroepera buxifolia & $011121212 ? 01100101001000001001000 ? 0000000000000110 ? 0$ \\
\hline Kairothamnus & $0111211130 ? ? ? ? ? ? ? ? ? ? ? ? ? 0001001000 ? 0000000000 ? 001100 ?$ \\
\hline
\end{tabular}


TABle 3. Continued.

\begin{tabular}{lc}
\hline \hline & Characters \\
\cline { 2 - 2 } \multicolumn{1}{c}{ Taxa } & 0000000001111111111222222222233333333334444444444555 \\
Scagea & 1234567890123456789012345678901234567890123456789012 \\
Neoroepera banksii & $0111211130 ? ? ? ? ? ? ? ? ? ? ? ? ? 0001001000 ? 000000000000011110$ \\
Micrantheum & $01112 ? 113001100101001000001001100 ? 0001000000000110 ? 0$ \\
Pseudanthus & $01112111300110010100111 ? 001001100 ? 1001000000 ? 0011010$ \\
Stachystemon & $011121113001100101001110001001100 ? 110100000000011010$ \\
\hline
\end{tabular}

remaining outgroup taxa (Table 3). The entire tree (with all the taxa in Euphorbiaceae we included) has a length of 34 steps and a consistency index (C.I.) of 0.47 . The portion of the tree including just the Oldfieldioideae, as shown in Figure 28, is 24 steps long and has a C.I. of 0.62 .

Though large portions of the tree are unresolved (as would be expected with only eight characters), our pollen data show several significant synapomorphies. As previously noted by Punt (1962, 1987), Köhler (1965), Webster (1975, 1994), and Hayden et al. (1984), Oldfieldioideae pollen is echi- nate (5: 2; character number: state number from Table 2) and has apertures that are brevicolporate to pororate to porate $(4: 1)$ and greater than three in number (2: 1). It was these characteristics that initially prompted Köhler (1965) and Webster (1975) to recognize the subfamily. When Kuhlmann (1935) described Paradrypetes he allied it with Drypetes Vahl in Phyllanthoideae. Hutchinson (1969) was the first to place Paradrypetes with genera now placed in Oldfieldioideae, presumably because of its opposite leaves; these pollen data offer clear support for his innovation. Scagea,

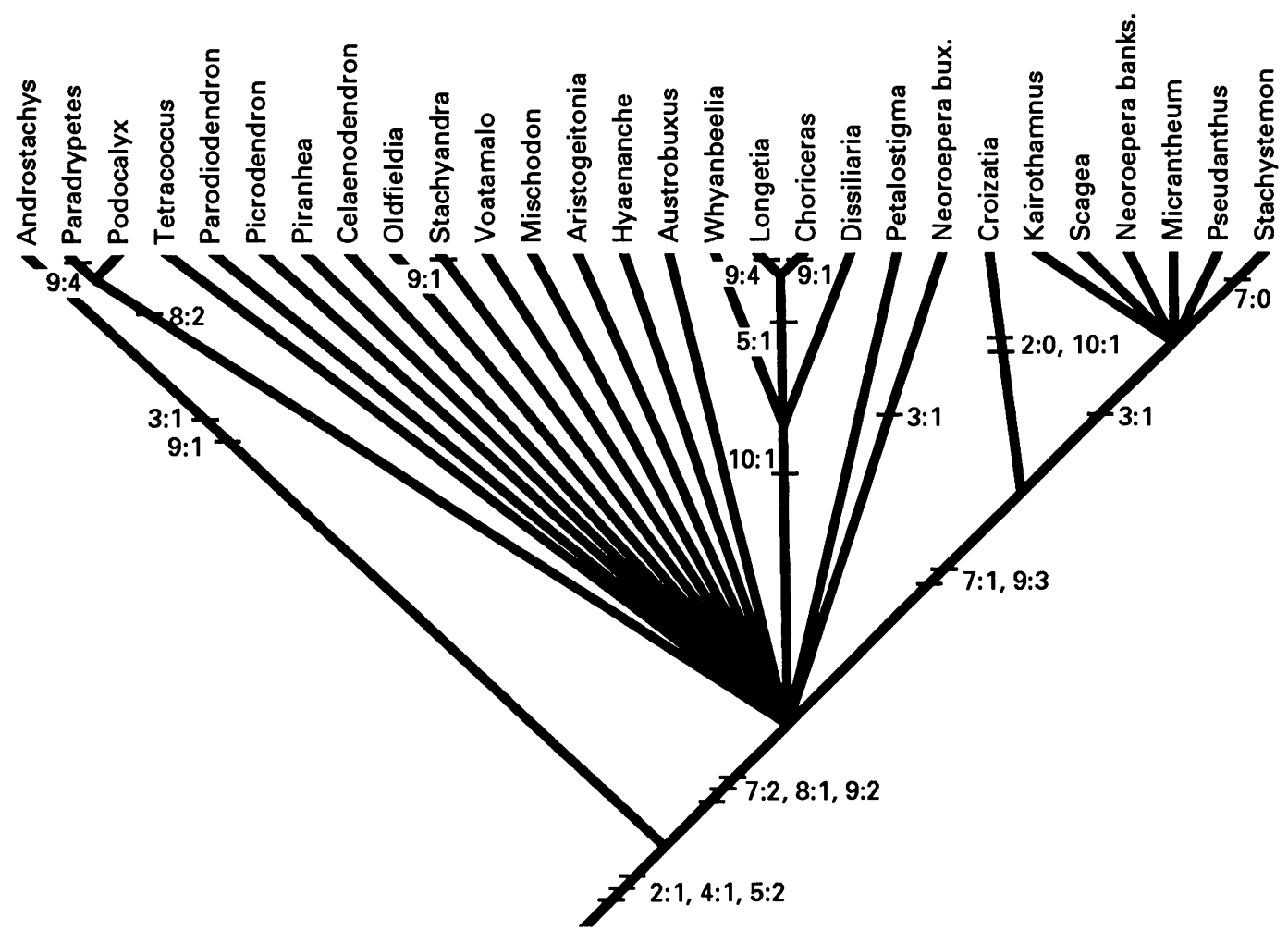

FIGURE 28. Strict consensus cladogram of the Oldfieldioideae based on palynological characters (1-5, 7-10) alone. In this and the following cladograms character state changes are shown by the character number, a colon, and the number of the derived state (see 'Table 2). 
too, shares these synapomorphies. Note that though Croizatia is well nested within the Oldfieldioideae, it has only three apertures (2: 0). Securinega also has echinate pollen, but has three colporate apertures $(2: 0,4: 0)$; it also lacks other synapomorphies shared by the Oldfieldioideae (see below). It would appear then that echinate sculpture is convergent in Securinega and the genus should remain in the Phyllanthoideae. Whether the oblate to globose shape is apomorphic or plesiomorphic for Oldfieldioideae cannot be resolved with our data.

Based on pollen alone, Androstachys would appear to be the sister group of the rest of the Oldfieldioideae and not to be closely related to Stachyandra. Three ultrastructural features appear to be synapomorphies of the rest of the subfamily: the foot-layer is irregular or absent (7: 2), the columellae are discontinuous with the foot-layer where it is present (8: 1), and the tectum is microperforate/baculate (9: 2). This last state was first recognized by Hayden et al. (1984) who examined Austrobuxus and Picrodendron. The pollen characters we used are remarkably uniform among most of the subfamily, hence the large polychotomy at this level in the tree.

Palynological characters allow recognition of several multigeneric clades at this level. The first clade, consisting of Paradrypetes (Fig. 21) and Podocalyx (Fig. 20), is united on the basis of their having the interstitium reduced or absent (8: 2). Because we treated the interstitial character as unordered, it is almost equally parsimonious to treat this state as synapomorphic for the entire subfamily and thus symplesiomorphic for these two genera. In that case, having columellae discontinuous with the foot-layer would be synapomorphic for the remaining genera of Oldfieldioideae. However, all the genera in Phyllanthoideae that we examined have a well-developed interstitium consisting of columellae that are continuous with the foot-layer, so it is more parsimonious to interpret the reduction of the interstitium as apomorphic.

The second clade, consisting of Choriceras, Dissiliaria, Longetia (Fig. 23), and Whyanbeelia, is defined by the presence of ektexinous periapertural thickenings (10: 1). Within this clade, Choriceras and Longetia form another clade, sharing reduced spines less than $1 \mu \mathrm{m}$ long (5: 1); it is easy to understand why Punt (1962) and Köhler (1965), using only LM, described the pollen of these genera as psilate. The tectum in Choriceras, which is microperforate/homogeneous (9: 1), may actually be transitional between the microperforate/baculate condition and the imperforate tectum (9:4) of Longetia.
Another clade, consisting of Croizatia (Fig. 16), Kairothamnus, Scagea (Fig. 24), Neoroepera banksii, Micrantheum (Figs. 9, 10), Pseudanthus (Figs. 1 1, 12), and Stachystemon (Fig. 25), shares a thick, homogeneous foot-layer (7: 1), first noted by Köhler (1965), and a microperforate/granular tectum (9: 3). Croizatia is the sister group of the remaining taxa, all of which share pantoporate apertures (3: 1). On this basis, Neoroepera, Micrantheum, Pseudanthus, and Stachystemon were previously recognized as a group by Punt (1962), Köhler (1965), and Webster (1975), who united them in the Pseudanthinae (Kairothamnus and Scagea had not yet been described). As previously noted by Köhler (1965), Neoroepera buxifolia (Figs. 3, 4), though pantoporate, has the exine structure typical of most Oldfieldioideae and therefore lacks the synapomorphies that place $N$. banksii in this clade. In all the equally most parsimonious trees, the pantoporate condition in Androstachys is convergent with the pantoporate condition in both this clade and Neoroepera buxifolia (cf. Fig. 28).

Combined character set. As might be expected given the greater number of characters, cladistic analysis of the entire data set yielded much better resolution of relationships. We again dropped pollen nonspinal sculpturing (character 6) from the analysis because of its relatively high homoplasy and our difficulty in determining the character states of many taxa (but see further discussion of this character below). Several hundred equally parsimonious trees resulted. We did not search the sets of trees resulting from different choices of outgroups for duplicate cladograms so we cannot state the precise number of equally parsimonious trees. We did compare the clade consisting of the Oldfieldioideae, however, and found 24 equally parsimonious arrangements of these taxa. Figure 29 illustrates the strict consensus tree for the relationships among the taxa of Euphorbiaceae we included and Figure 30A shows the strict consensus tree for the Oldfieldioideae. The trees including all the Euphorbiaceae taxa are 128 steps long (C.I. $=0.47$ ) if all characters are included, or 124 steps long (C.I. $=0.45)$ if the autapomorphies are excluded. The 24 trees including just the Oldfieldioideae are 104 steps long (C.I. $=0.54$ ) if all characters that vary among these taxa are included, or 97 steps long (C.I. $=0.50$ ) if autapomorphies are excluded. Cladistic analysis of the data from vegetative morphology and anatomy data alone (taken from Hayden, 1994) yielded similar but less resolved trees. 


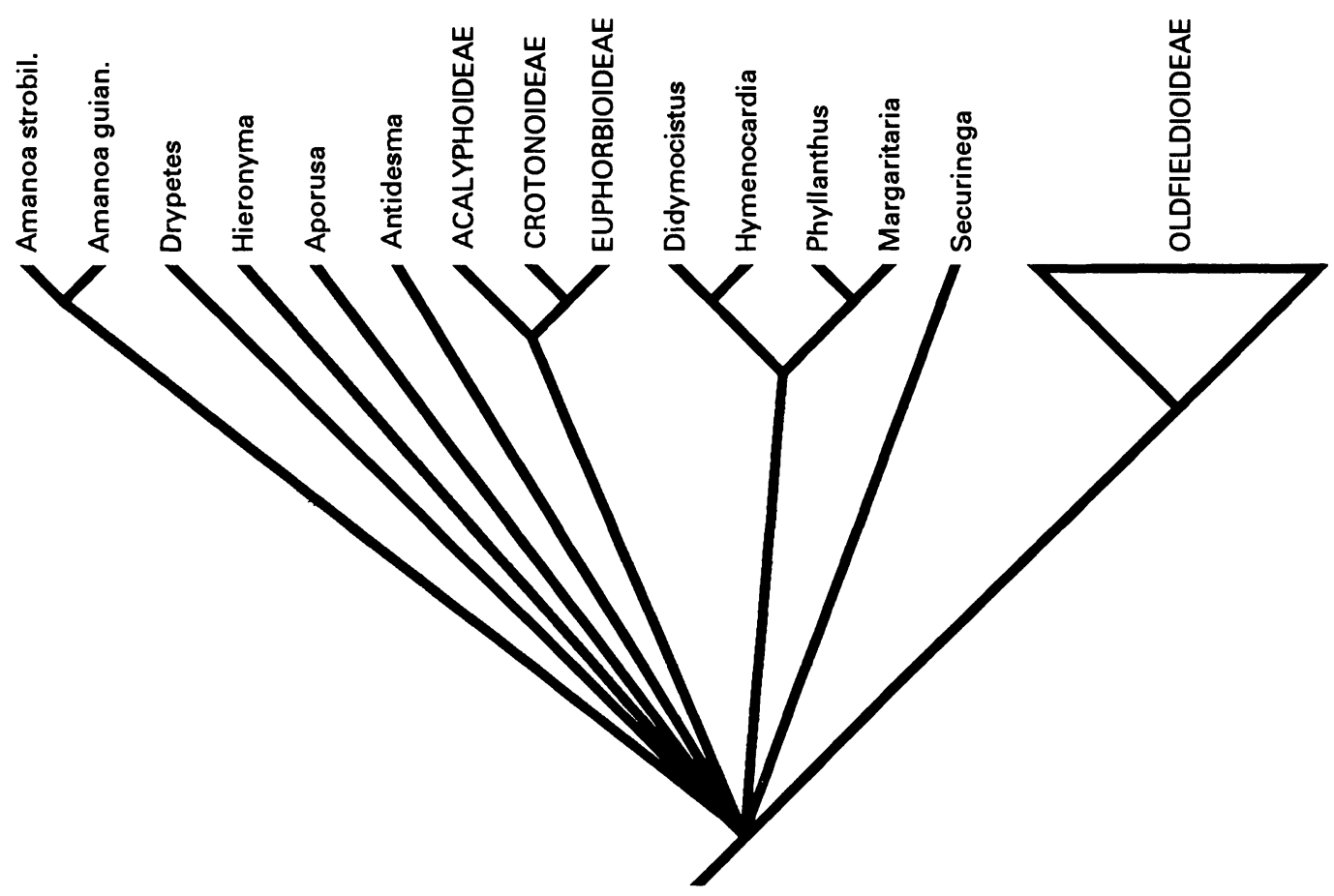

FIGURE 29. Strict consensus cladogram of the taxa of Euphorbiaceae included in our study, based on palynological, vegetative, and reproductive characters $(1-5,7-52)$. Names in all capital letters are of subfamilies. The phylogeny of the Oldfieldioideae, represented here by a triangle, is shown in Figure 30.

The polychotomy in clade $\mathrm{A}$ of Figure $30 \mathrm{~A}$ is a consequence of the polymorphism in phyllotaxy (character 25) found in Oldfieldia; the trichotomy and both dichotomous resolutions are equally parsimonious. Accepting this polychotomy as unresolvable reduces the number of substantially different equally parsimonious cladograms for the Oldfieldioideae to eight. A fundamental difference among these eight cladograms is the placement of Tetracoccus and the clade consisting of Paradrypetes and Podocalyx. Three different arrangements are equally parsimonious (Fig. 30B-D). All but the three cladograms with the basic arrangement shown in Figure 30B require two reversals that we consider unlikely: derivation of scalariform perforation plates from simple perforation plates (character 12) and derivation of transitional intervascular pitting from alternate intervascular pitting (character 13). The vessels of both genera of Oldfieldioideae known to have scalariform perforation plates and transitional intervascular pitting, Paradrypetes and Podocalyx, are about 1.0-1.4 mm long, much longer than those of other Oldfieldioideae, which are typically about $0.3-0.4 \mathrm{~mm}$ long (Hayden, 1980; Matos Araujo \& Mattos Filho, 1984), which is consistent with the interpretation that these character states are plesiomorphic. These three cladograms differ only in the relative positions of Austrobuxus, Dissiliaria, Hyaenanche, Petalostigma, Whyanbeelia, and the clade consisting of Choriceras plus Longetia within clade B of Figure 30. Two of these three cladograms are also those obtained using the successive weighting method of Farris (1969), which weights characters with low homoplasy greater than those with high homoplasy. These two cladograms, which we prefer because they do not require improbable reversals and are better supported by what we consider the more reliable characters (those with low homoplasy) are shown in Figures 31-33. (The third cladogram, not shown, is similar to Fig. 33A but with Hyaenanche the sister group of the clade consisting of Austrobuxus, Choriceras, Dissiliaria, Longetia, and Whyanbeelia.) In contrast to the polychotomy involving Oldfieldia (Figs. 30A and 32), the polychotomies shown in Figure 33 result from absence of synapomorphies (zero branch lengths) rather than character conflicts and therefore cannot be further resolved with our data.

The trees produced using pollen data alone (e.g., Fig. 28) are almost entirely consistent with our preferred trees produced using all the data (Figs. 

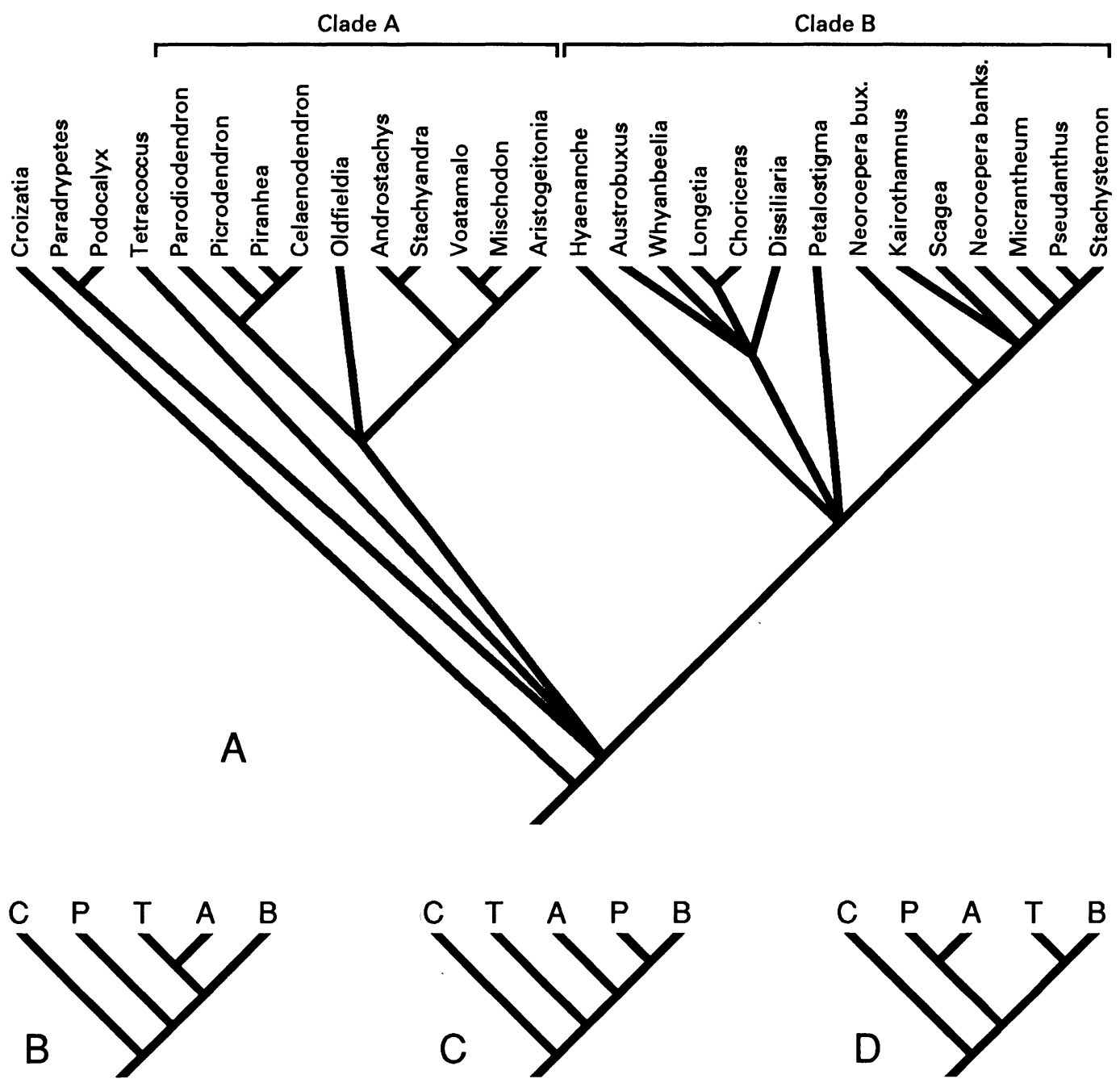

FIGURE 30. Cladograms of the Oldfieldioideae, based on palynological, vegetative, and reproductive characters (1-5, 7-52). - A. Strict consensus cladogram. Clades A and B are two major clades that appeared in all the equally most parsimonious cladograms.-B-D. Cladograms showing the three equally most parsimonious arrangements of Croizatia ("C"), Tetracoccus ("T"), the clade consisting of Paradrypetes plus Podocalyx ("P"), and clades A and B.

$31-33)$. The two exceptions are the positions of Androstachys and Croizatia. Instead of being basal, as in the pollen-based cladogram (Fig. 28), Androstachys forms a clade with Stachyandra, to which it certainly is closely related (RadcliffeSmith, 1990). This relationship is supported by three synapomorphies: microperforate/homogeneous tectum (9: 1), foliar veins beyond the tertiaries indistinguishable in a reticulum (41: 1), and the presence of columnar foliar sclereids (44: 1); in addition, these genera share rather unusual floral morphology, notably the staminate inflorescences which consist of a triad of flowers, each with numerous stamens borne on an elongate androphore
(Airy Shaw, 1970; Dahlgren \& van Wyk, 1988; Radcliffe-Smith, 1990). In turn, a sequence of morphological synapomorphies (notably circular and alternate vessel-ray pits (18: 1), compound or unifoliolate leaves $(24: 1,2)$, well-developed bundle sheath extensions (33: 1), fimbriate marginal ultimate venation (39: 1), well-developed areoles (42: 1), and epipetiolar stipules (46: 1)) cause Androstachys and Stachyandra to be nested well up within the Oldfieldioideae (Figs. 31, 32). Placing Androstachys at the base of the subfamily, as shown in Figure 28, increases the length of the combined data set tree by at least nine steps, and placing Androstachys and Stachyandra together at the 


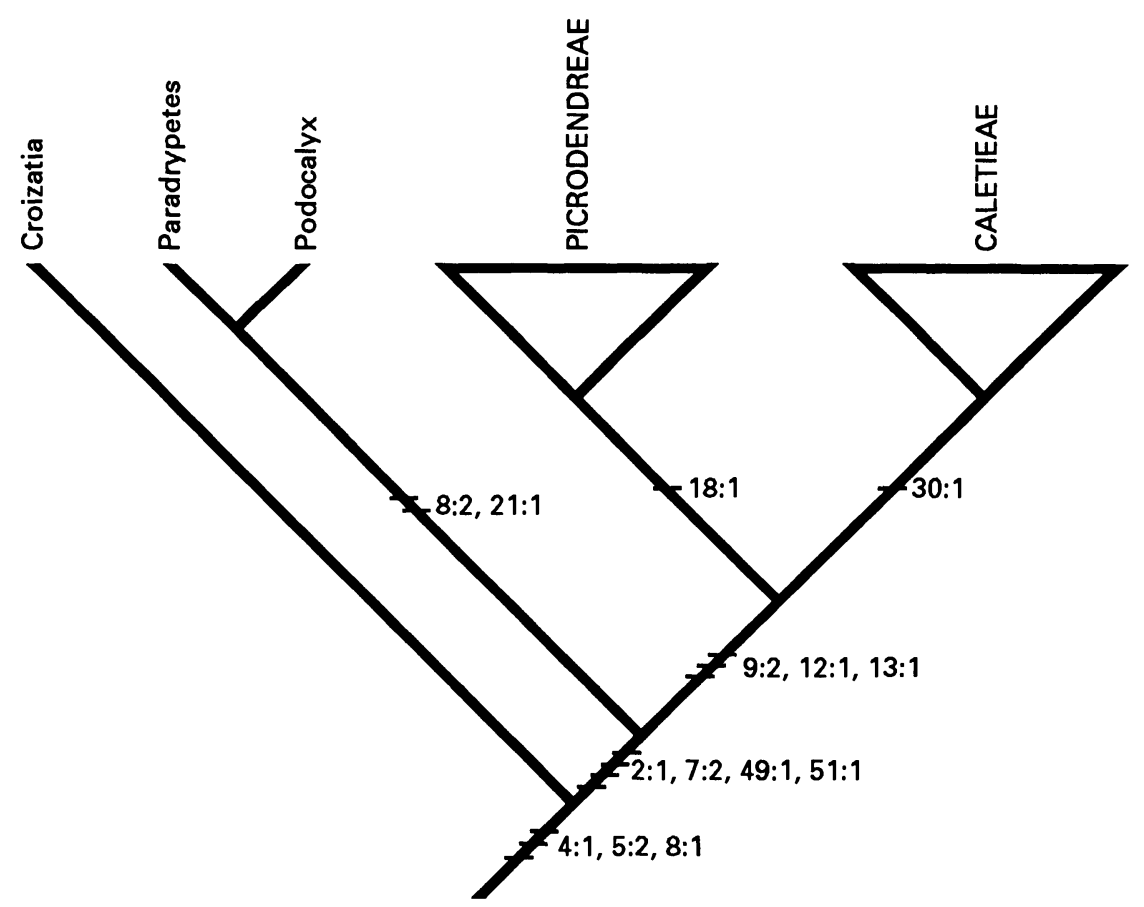

FIGURE 31. Preferred most parsimonious cladogram of the Oldfieldioideae based on palynological, vegetative, and reproductive characters $(1-5,7-52)$. Triangles represent tribes whose subtribal relationships are shown in Figures 32 and 33 . Only synapomorphies are shown, so some characters are more homoplastic than indicated.

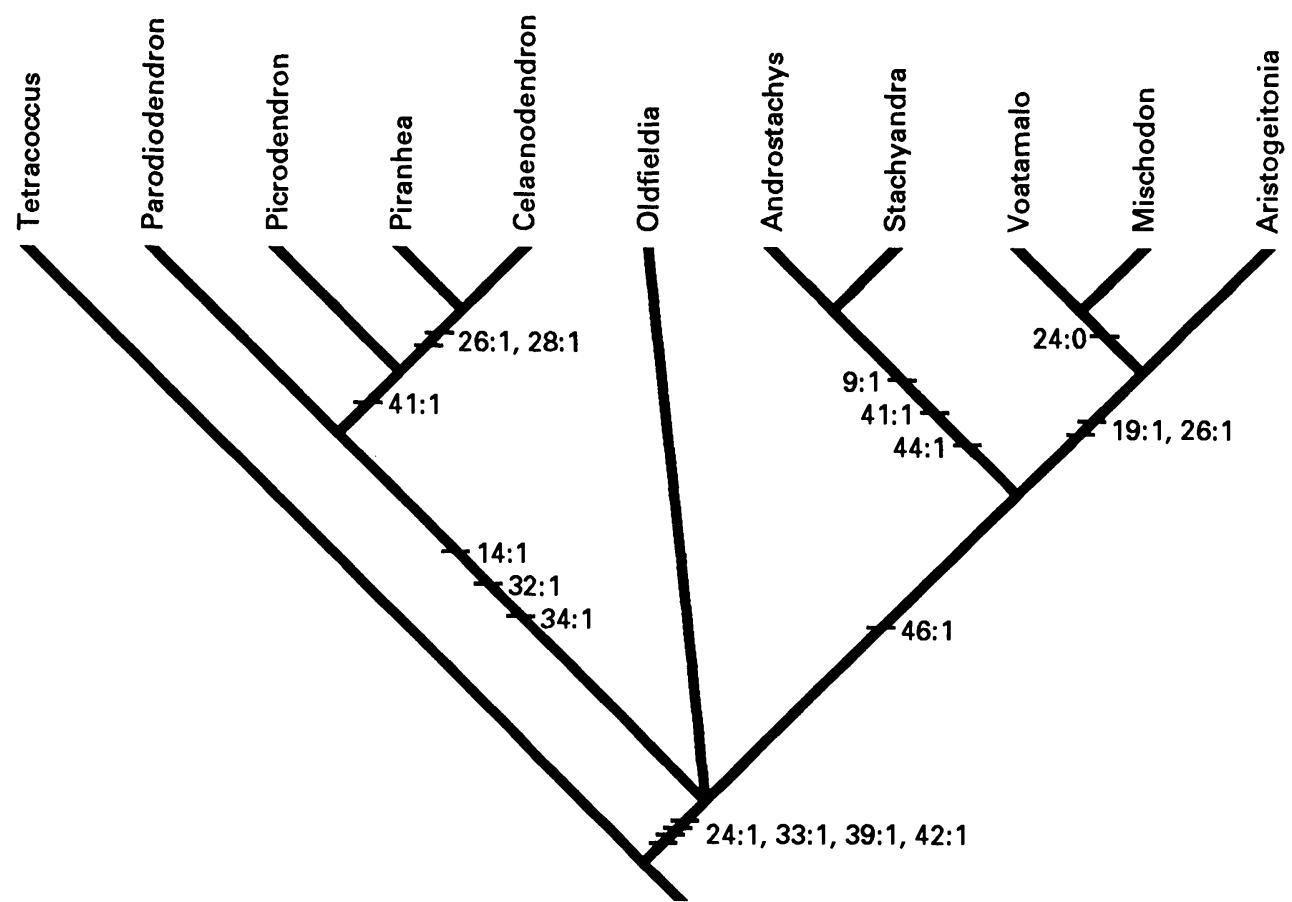

Figure 32. Preferred most parsimonious cladogram of Oldfieldioideae tribe Picrodendreae based on palynological, vegetative, and reproductive characters $(1-5,7-52)$. Only synapomorphies are shown, so some characters are more homoplastic than indicated. 

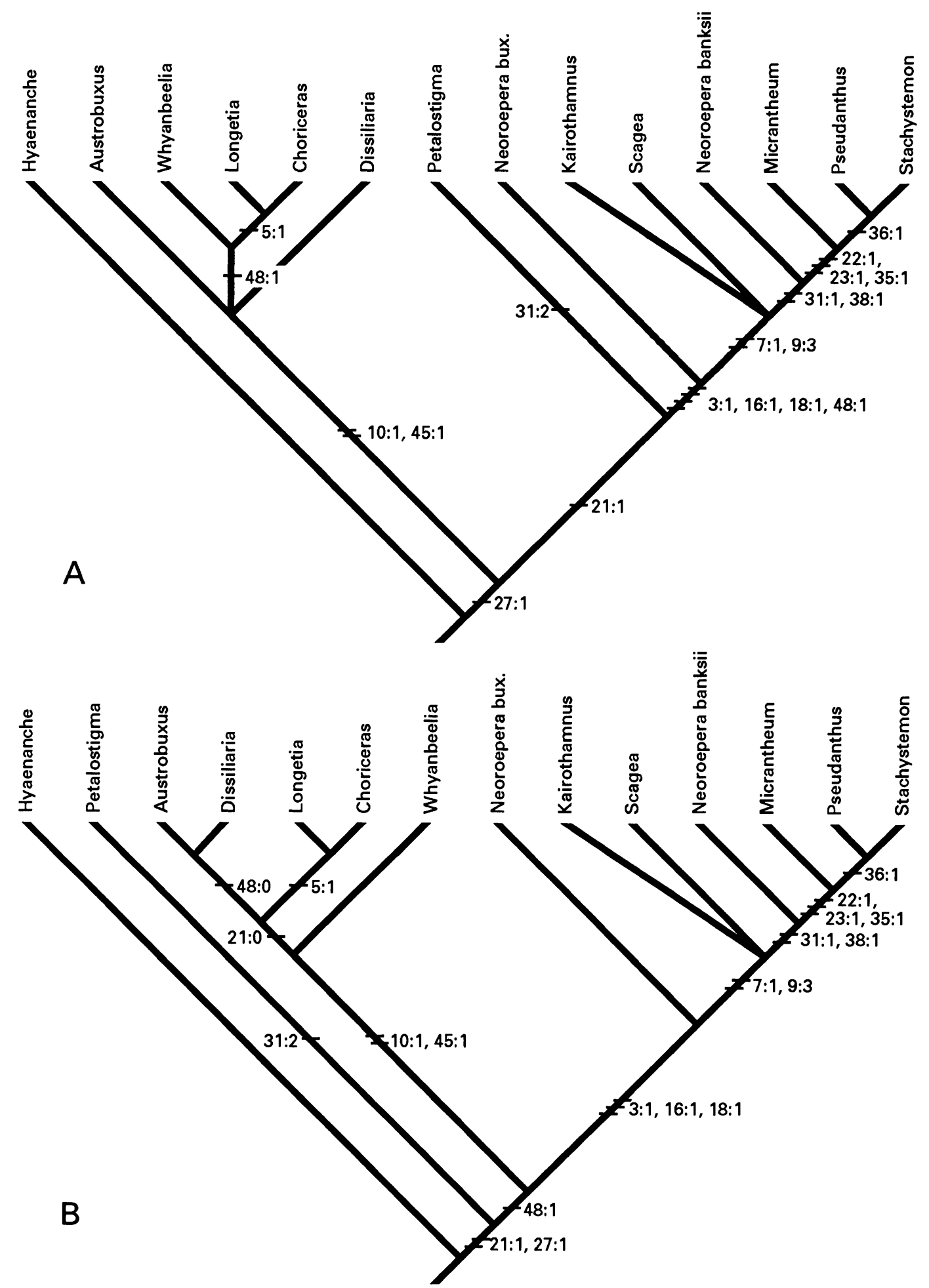

FigURE 33. The two preferred most parsimonious cladograms (A, B) of Oldfieldioideae tribe Caletieae based on palynological, vegetative, and reproductive characters $(1-5,7-52)$. With the exception of character 31 , only synapomorphies are shown, so some characters are more homoplastic than indicated. 


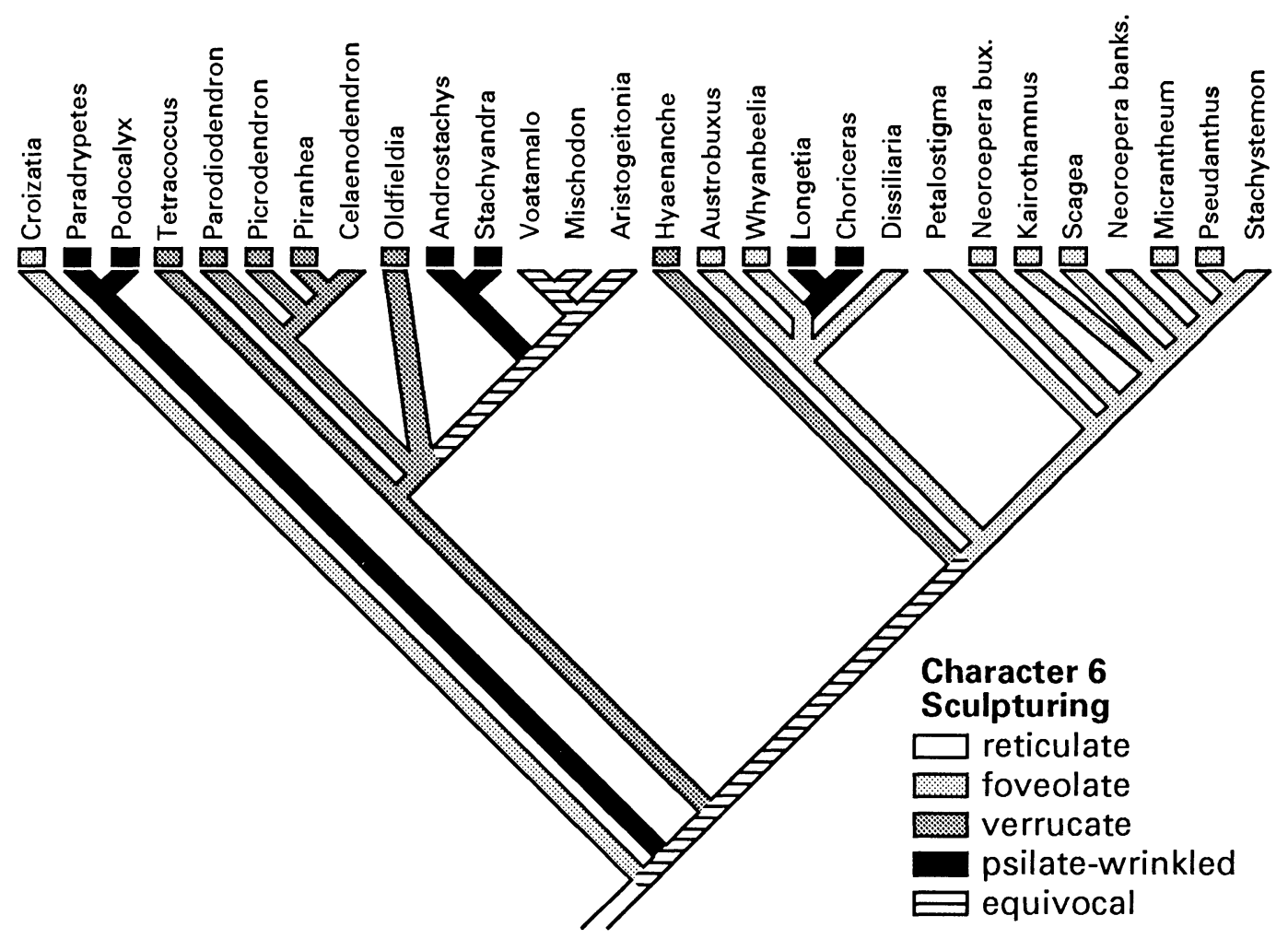

Figure 34. Cladogram of the Oldfieldioideae showing character 6, nonspinal sculpturing. Character states found in the taxa are shown by boxes below the taxon names; where there is no box we do not know the state found in that taxon. Note wide distribution of equivocal character states due to homoplasy and unknown states in many taxa.

base requires at least seven additional steps. In contrast, placing Androstachys with Stachyandra increases the length of the pollen-based tree by only two steps, namely reversals to a thin, homogeneous foot-layer (7: 0 ) and columellae continuous with the foot-layer (8: 0$)$. The plesiomorphic states for the exine foot-layer and interstitium (characters 7 and 8) found in Androstachys are therefore better regarded as reversals rather than as ancestral conditions.

Two characters of reproductive morphology, absence of petals (49: 1) and presence of a caruncle (51: 1 ), combine with pollen having more than three apertures (2: 1) to support the monophyly of the Oldfieldioideae less Croizatia, resulting in the latter genus occupying the basal position in the subfamily (Figs. 30, 31) when our entire data set is considered. Making Croizatia the sister group of the clade comprising Kairothamnus, Micrantheum, Neoroepera banksii, Pseudanthus, Scagea, and Stachystemon, as suggested by pollen alone (Fig. 28), increases the length of the combined data set tree by five steps, whereas placing Croizatia at the base of the pollen-based tree requires only one additional step. The similarities in exine structure these taxa share, i.e., thick, homogeneous foot-layer (7: 1) and microperforate/ granular tectum (9: 3), therefore appear to be convergent between Croizatia and the remaining taxa. We must point out that the wood and leaf anatomy of Croizatia remains unknown; when studied, such data may support or contradict this hypothesis.

The results of this analysis clarify the synapomorphies of the Oldfieldioideae. As suggested by the tree based on pollen data alone, brevicolporate apertures (4: 1) and echinate pollen (5: 2) are synapomorphies of the subfamily. However, having more than three apertures (2: 1 ) is not a synapomorphy of the entire subfamily because the basal genus, Croizatia, retains the plesiomorphic state of three apertures. The phylogenies illustrated in Figures 31-33 show that having columellae discontinuous from the foot-layer (8: 1) is a further synapomorphy of the subfamily. In addition, though we deleted nonspinal sculpturing (character 6) from our final cladistic analysis and data are missing for several taxa, several patterns can be seen (Fig. 34). Notably, no Oldfieldioideae are known to have reticulate sculpturing $(6: 0)$, the prevalent condi- 
TABLE 4. Proposed classification of the Oldfieldioideae. Suprageneric taxa are arranged such that each taxon is the sister group of the taxa of equal rank following it in sequence. "(T)" indicates each type genus.

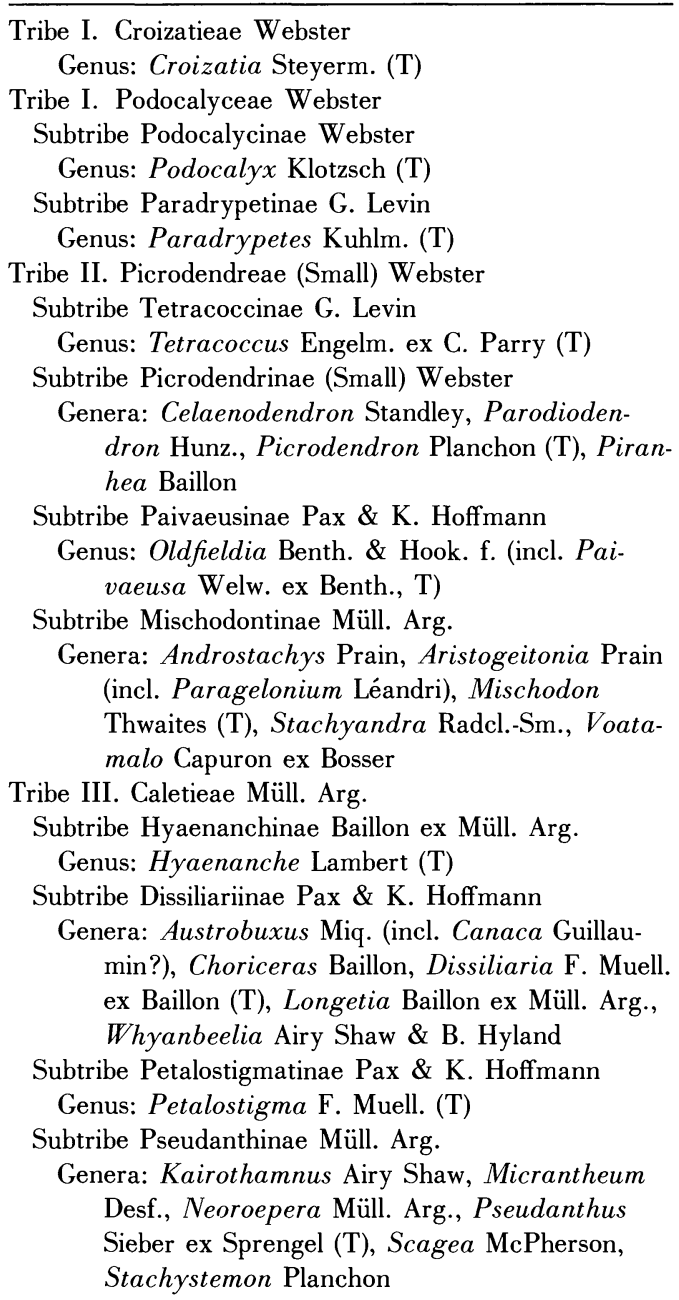

tion in the Phyllanthoideae. Therefore nonreticulate sculpturing may be said to characterize the Oldfieldioideae.

Further aspects of pollen character evolution are discussed by Simpson \& Levin (in press), and evolutionary patterns of most of the vegetative characters have been discussed by Hayden (1994). Here we will concentrate on the taxonomic implications of the synapomorphies shown in Figures 31-33.

\section{TAXONOMIC IMPLICATIONS}

Since Köhler (1965) first recognized the Oldfieldioideae as a distinct subfamily and subdivided it into tribes, three further treatments of the subfamily have been proposed. Hutchinson (1969) did not recognize any subfamilies, and his treatment can be essentially ignored because he disregarded the palynological data compiled by Punt (1962) and Köhler (1965) and scattered the oldfieldioid genera among five tribes, three of them also containing phyllanthoid genera. He was the first, however, to place Paradrypetes with other genera of the Oldfieldioideae. Webster $(1975,1994)$, in contrast, relied heavily on palynology and presented major reorganizations of the subfamily. With the exception of Webster's (1994) recent classification, none of these treatments agrees very well with either of the preferred phylogenies based on our combined data set (Figs. 31-33).

Though we are somewhat reluctant to propose a formal classification of the Oldfieldioideae given the paucity of reproductive morphological data in our analysis, we find it useful to summarize our findings in the form of a system. We therefore propose the classification shown in Table 4 and Figure 35, in which all the suprageneric taxa are monophyletic according to our preferred phylogenies (Figs. 31-33). We have not given coordinate taxa equal rank, but for suprageneric taxa have followed the sequencing convention proposed by Wiley (1979, 1981: 205-225), wherein each taxon is the sister group of the taxon or taxa of equal rank following it in sequence. Within suprageneric taxa we list genera alphabetically. Our classification is almost identical to that of Webster (1994), differing only in the placement of Tetracoccus (see below).

We divide the Oldfieldioideae into four tribes. The first tribe, the Croizatieae, consists solely of the genus Croizatia. The remaining Oldfieldioideae share two unique synapomorphies (Fig. 31): pollen with more than three apertures (2: 1) and petals absent (49: 1). Two homoplastic synapomorphies also characterize the rest of the Oldfieldioideae: exinous foot-layer reduced or absent (7: 2; Fig. $36)$, which shows further evolution and convergence elsewhere in the tree, and caruncles present on the seeds (51: 1), which shows repeated losses in isolated genera. It is tempting to view opposite or whorled leaves (25: 1; Fig. 37) as a synapomorphy of the Oldfieldioideae above Croizatia, because opposite or whorled leaves (25: 1) are common in the Oldfieldioideae and leaves of the Phyllanthoideae are consistently alternate, as are leaves of the primitive members of the other subfamilies. In fact, this character varies in such a way that it is impossible, using parsimony alone, to determine the state at most levels within the 


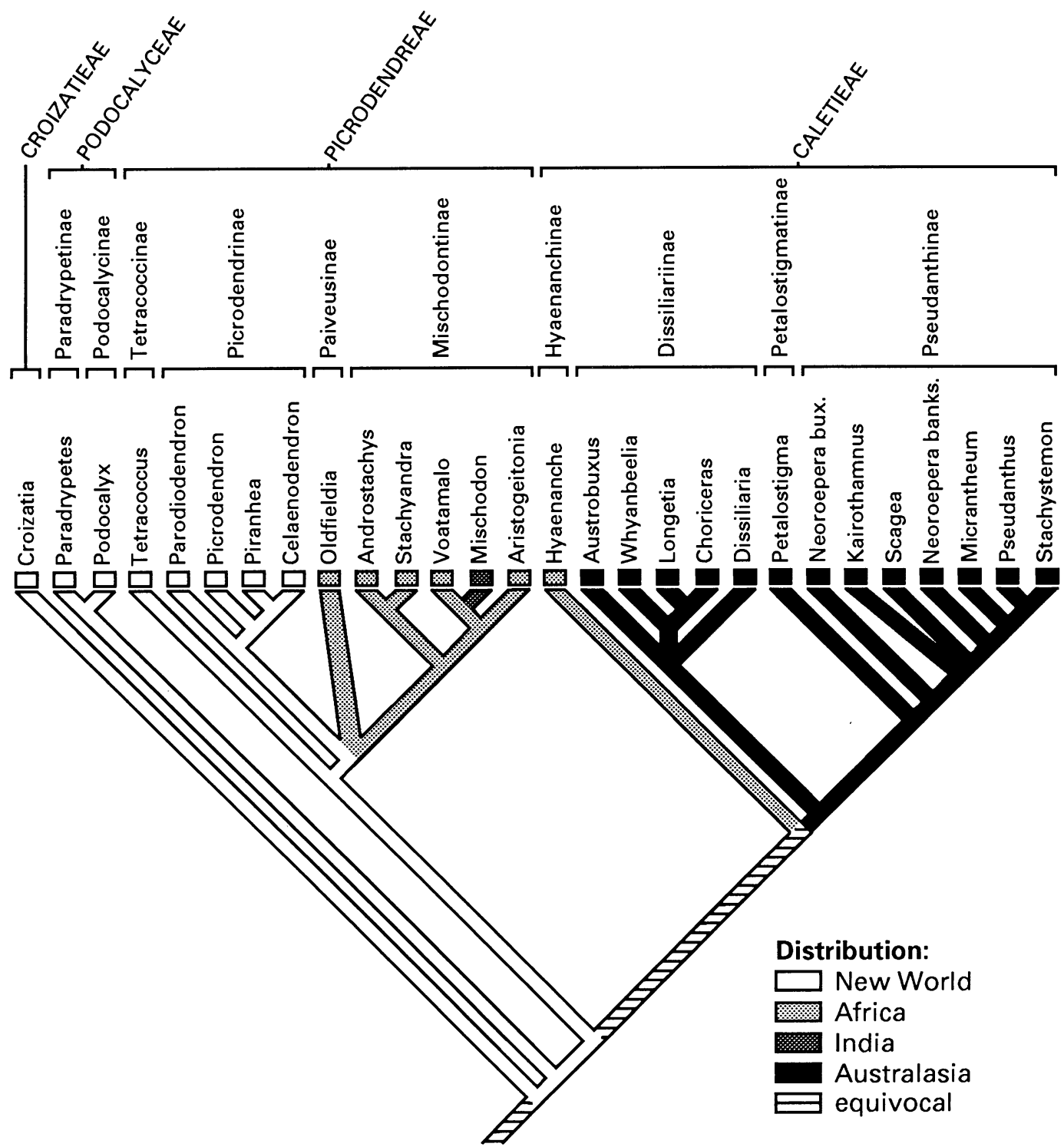

FIGURE 35. Cladogram of Oldfieldioideae showing the geographic distribution of the taxa and our proposed classification of the Oldfieldioideae.

subfamily (Fig. 37). In Picrodendron, the first pair of leaves above the cotyledons are opposite, though the remaining leaves are alternate (Hayden et al., 1984). Examination of the other alternate-leaved Oldfieldioideae could clarify whether this is developmental evidence that could aid in the determination of the polarity of this character.

Given the number of synapomorphies shared by most of the Oldfieldioideae but lacking in Croizatia (Fig. 31), it could argued that this genus should be retained in the Phyllanthoideae. Our data, however, leave little doubt that Croizatia is the sister group of the remaining Oldfieldioideae. Furthermore, the position of Croizatia is ambiguous if it is retained in the Phyllanthoideae (Webster et al., 1987). We therefore find it more informative to treat Croizatia as the basal member of the Oldfieldioideae.

The second tribe, the Podocalyceae, is supported by a single unique synapomorphy, reduction or loss of the interstitial elements in the exine (8: 2). In addition, unsclerified crystalliferous axial xylem parenchyma (2l: 1$)$, convergent elsewhere in the tree, supports this clade (Fig. 31). Psilate-wrinkled 


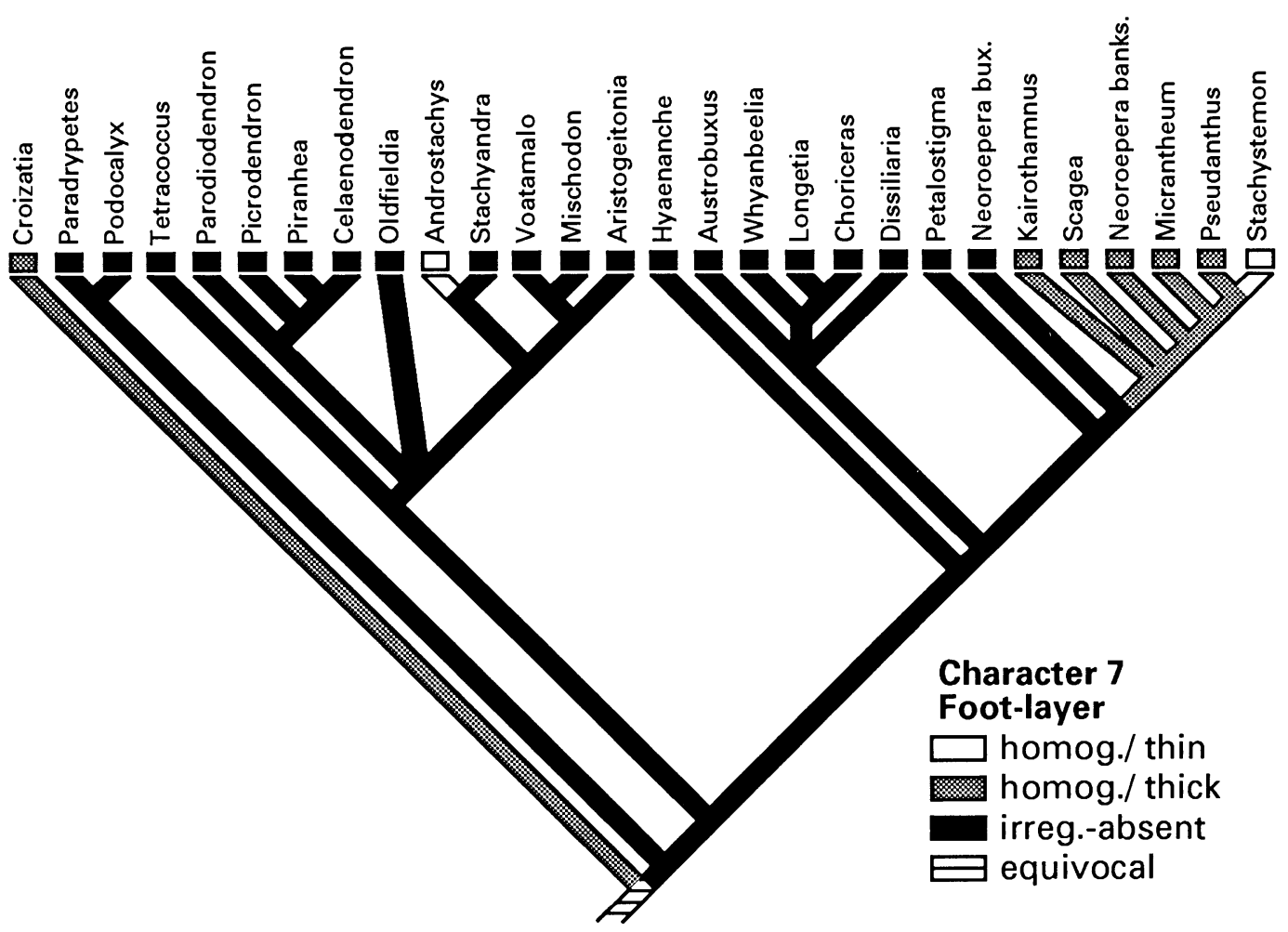

FIGURE 36. Cladogram of Oldfieldioideae showing character 7, pollen ektexinous foot-layer.

nonspinal sculpturing (6: 4) may also be a synapomorphy of this clade, but unfortunately the ancestral state for this character in the Oldfieldioideae is ambiguous (Fig. 34). Because Paradrypetes and Podocalyx are so different from each other (Levin, 1992), we place each in its own subtribe.

The rest of the Oldfieldioideae share two unique synapomorphies (Fig. 31), simple perforation plates (12: 1) and alternate intervascular pitting (13: 1), and one, microperforate/baculate tectum (9: 2; Fig. 38), that evolves to other derived states higher within the clade. It is tempting to interpret verrucate nonspinal sculpturing (6: 3) as a synapomorphy of this clade, but the ancestral state is equivocal (Fig. 34). We divide this clade into two tribes representing a major split within the subfamily.

The first of these tribes, the Picrodendreae (Fig. 32 ), is defined by having alternate vessel-ray pitting (18: 1), a synapomorphy that is convergent elsewhere. Tetracoccus, the basal member of this clade, has several autapomorphies and we therefore propose placing it in its own subtribe, the Tetracoccinae (G. Levin in Webster, 1994). Webster placed the Tetracoccinae in the Podocalyceae, emphasizing that the pollen of Tetracoccus, like that of both
Paradrypetes and Podocalyx, has four brevicolporate apertures. This state appears to be plesiomorphic at this level in the tree, and treating $T e$ tracoccus plus the Podocalyceae as a monophyletic group lengthens the combined data trees (Figs. 3133) by three steps.

The rest of the Picrodendreae share four homoplastic synapomorphies (Fig. 32): compound or unifoliolate leaves $(24: 1,2)$, bundle sheath extensions (33: 1), fimbriate marginal venation (39: 1), and well-developed areoles (42: 1). We recognize three subtribes in the Picrodendreae, representing the three clades of this trichotomy. Oldfieldia, the sole genus of Paivaeusinae, has no synapomorphies that clearly unite it with either clade. Indeed, our data provide no support for the monophyly of Oldfieldia, which has four species; given the variation in phyllotaxy within the genus (Fig. 37), the possibility that it is not monophyletic should be examined. Genera in the American subtribe Picrodendrinae (Fig. 32) share one unique synapomorphy, loss of crystals in the mesophyll (32: 1), and two homoplastic synapomorphies, larger than typical intervascular pitting (14:1) and prismatic crystals in the bundle sheath extensions (34: 1). Leaves are uniformly alternate $(25: 0)$ in the Picroden- 


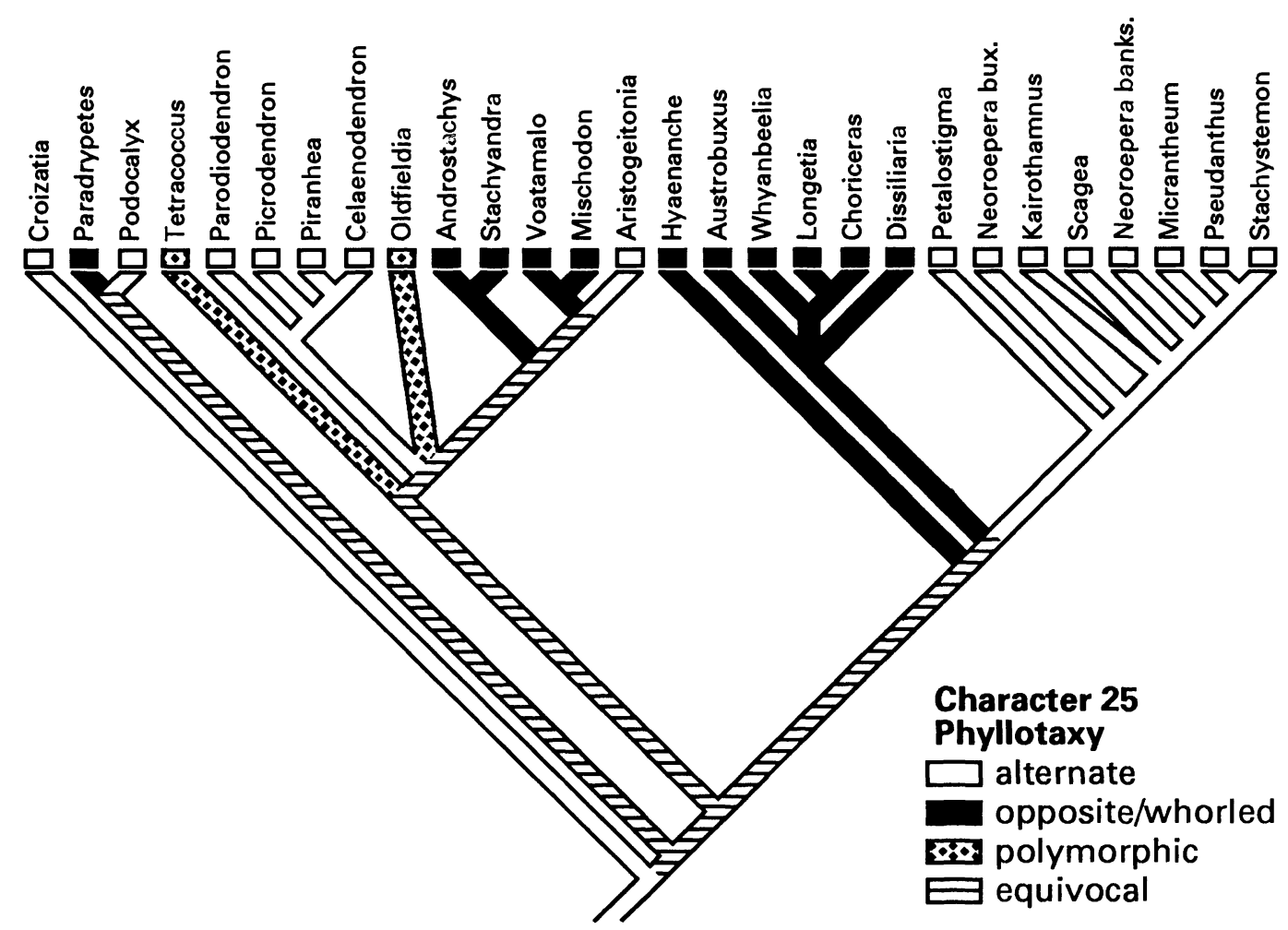

FIGURE 37. Cladogram of Oldfieldioideae showing character 25, phyllotaxy. Note that the polarity of this character within the Oldfieldioideae cannot be determined in most of the tree.

drinae, but whether this is a synapomorphy or a symplesiomorphy is equivocal (Fig. 37). Further homoplastic synapomorphies resolve relationships among the four genera in this subtribe (Fig. 32). The final subtribe we recognize in the Picrodendreae, the African/Indian Mischodontinae, shares the unique synapomorphy epipetiolar stipules (46: 1). Androstachys and Stachyandra form the basal clade, defined by one unique synapomorphy, columnar foliar sclereids (44: 1), and two homoplastic synapomorphies, homogeneous tectum (9: 1; Fig. 38 ) and vein order beyond the tertiaries indistinguishable (41: 1). The remaining genera share the homoplastic synapomorphy of sclerified crystalliferous ray cells (19: 1). As we noted above in the discussion of this character, interpretation of this character in the Phyllanthoideae and the outgroups is somewhat doubtful. However, this clade is also supported by the homoplastic synapomorphy of epidermal mucilage lacking (26: 1). Reversal to simple leaves (24: 0) unites Mischodon and Voatamalo (Fig. 32).

The final tribe, Caletieae (Fig. 33), is defined by the unique synapomorphy of crenulate anticlinal walls on the subsidiary cells (30: 1, Fig. 31). The
South African genus Hyaenanche, the basal member of the clade, also is the sole member found outside Australasia (Fig. 35). We propose maintaining it in its own subtribe, recognizing its unique distribution and gross morphology. We are unable to choose between two slightly different phylogenies for the remaining genera in the tribe (Fig. 33) because our data support both equally well. All these genera share chambered epidermal cells (27: 1), a unique synapomorphy, and depending on the phylogeny chosen, the clade may also be defined by sclerified crystalliferous axial xylem parenchyma (21: 1). These genera also share nonverrucate sculpturing, either foveolate $(6: 1)$ or psilate-wrinkled (6: 4), but whether either of these states can be considered a synapomorphy at this level is equivocal (Fig. 34). In either case, we recognize three additional subtribes within the Caletieae.

Reduced or obsolete stipules (45: 1), a unique synapomorphy, and ektexinous periapertural thickenings (10: 1), convergent in Croizatia, unite the genera we assign to the subtribe Dissiliariinae (Fig. 33). Though our data for these two characters are incomplete for these taxa (see Table 3 and the discussion above of character 45), for each genus 


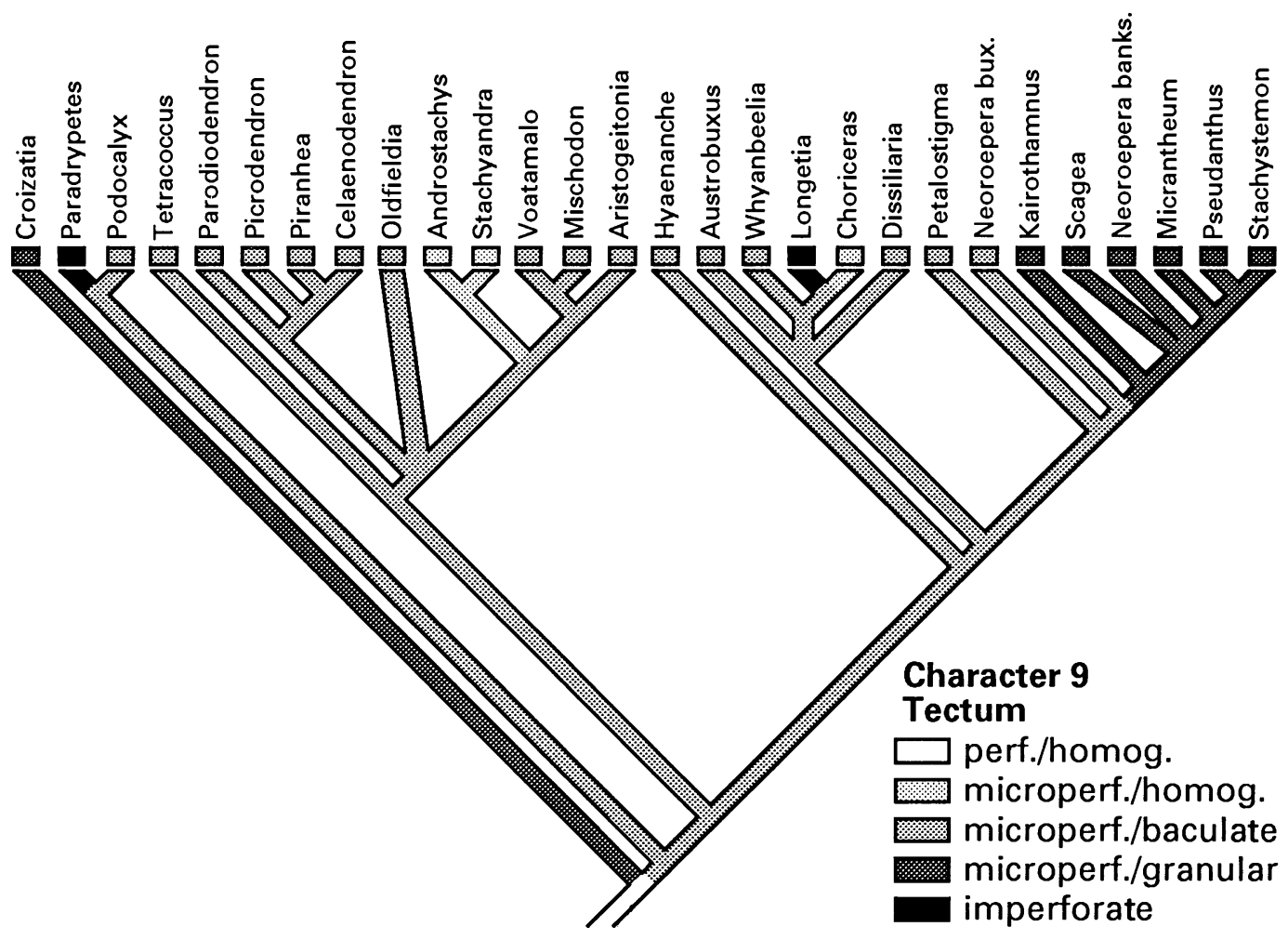

FigURE 38. Cladogram of Oldfieldioideae showing character 9, the tectum.

we have definite data for at least one of the characters. In combination, therefore, these two characters provide unequivocal support for this clade. Within the Dissiliariinae, sexuality (character 48) distinguishes Austrobuxus and Dissiliaria from Choriceras, Longetia, and Whyanbeelia (Fig. 33). Though authors, including Airy Shaw (1974, 1976, 1980) and McPherson (1985), have used sexuality as a means of segregating taxa from Austrobuxus, this is the first demonstration of the phylogenetic significance of this character in the Oldfieldioideae. Unfortunately, the polarity of this character at this level in the tree depends on the phylogeny chosen (Fig. 33). Choriceras and Longetia are united by minute pollen spines (5: 1), a unique synapomorphy. As noted above, the microperforate/homogeneous tectum (9: 1) of Choriceras can be interpreted as transitional between the microperforate/baculate tectum (9: 2) of most other Oldfieldioideae and the imperforate tectum (9: 4) of Longetia, further supporting a close relationship. Our data clearly support the separation of Longetia from Austrobuxus as advocated by McPherson \& Tirel (1987).

In recognition of its distinctive autapomorphies and its doubtful placement (Fig. 33), we maintain
Petalostigma in its own subtribe, the Petalostigmatinae. Whether this subtribe or the Dissiliariinae is more closely related to the final subtribe, the Pseudanthinae, is ambiguous (Fig. 33). As we discussed previously, some species of Petalostigma have pollen in which the apertures do not all lie on the equator. If this is transitional to the pantoporate condition in the Pseudanthinae, it would suggest that Petalostigma is more closely related to the Pseudanthinae. In either case, the thinwalled unlignified phloem fibers in the primary leaf vein of Petalostigma (31:2) appear to have evolved independently from the thick-walled unlignified phloem fibers of many of the Pseudanthinae (31: 1), demonstrating the lack of homology between loss of lignification in these two types of fibers.

The core genera of the Pseudanthinae, $M i$ crantheum, Pseudanthus, and Stachystemon, were first placed together in 1858 (Ågardh, 1858) and have remained so in virtually every system since then. Punt (1962) and Köhler (1965) recognized that Neoroepera is closely related to these genera-all share pantoporate pollen (3: 1) - and Webster (1975) added the genus to the subtribe. Now we can add Kairothamnus and Scagea, as their pollen, too, is pantoporate. These results also 


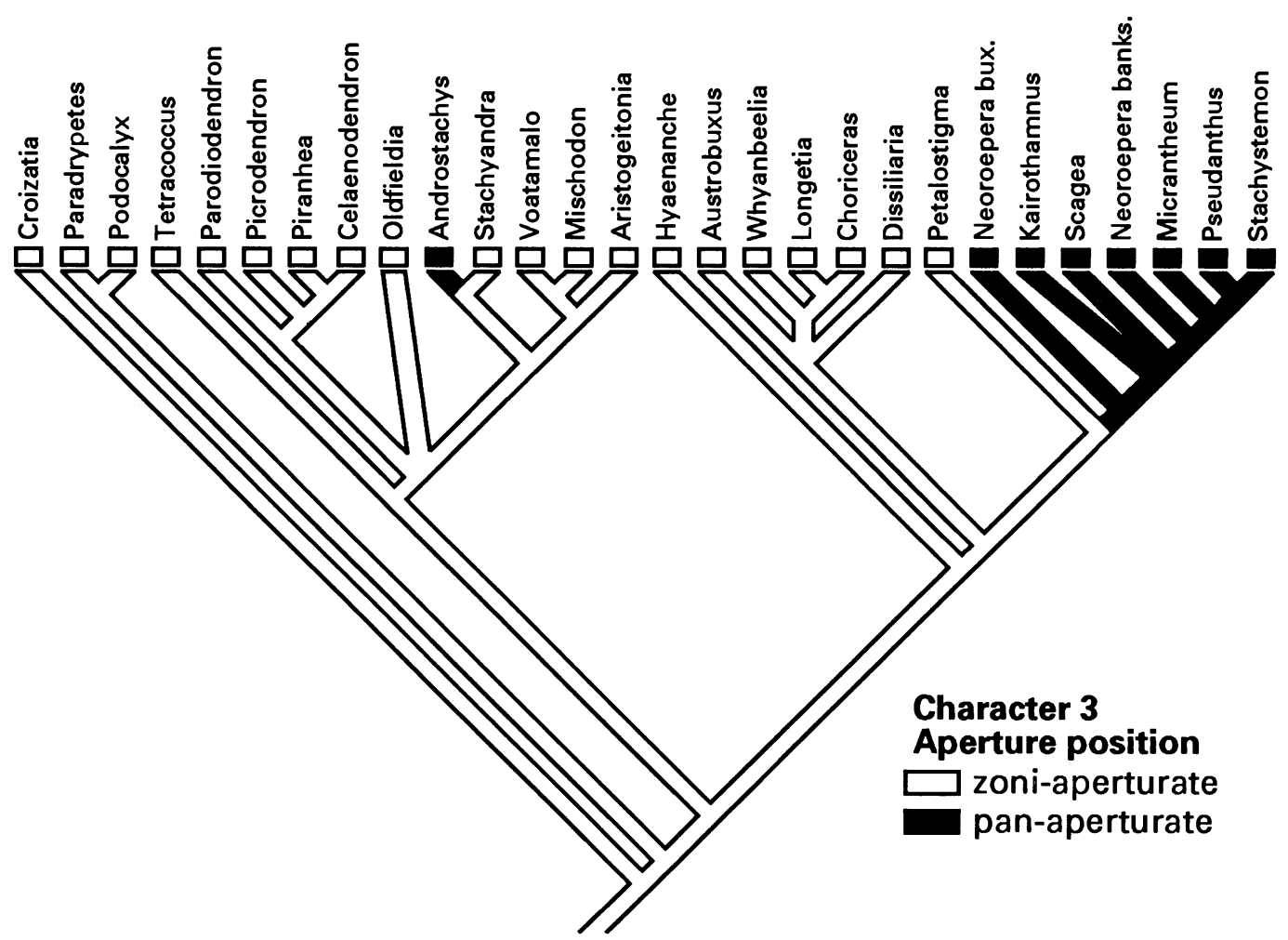

Figure 39. Cladogram of Oldfieldioideae showing character 3, pollen aperture position. Pan-aperturate pollen has evolved twice, once in Androstachys and once in the Pseudanthinae.

reinforce our earlier conclusion that pantoporate apertures evolved independently in Androstachys and in the Pseudanthinae (Fig. 39). The woods of Kairothamnus and Scagea have not been examined, but it appears that two wood synapomorphies, homocellular erect rays (16: 1 ; unique) and alternate vessel-ray pitting (18: 1 ; homoplastic), also unite the Pseudanthinae (Fig. 33). All the genera in the subtribe are monoecious (48: 1), but whether this is a synapomorphy of this subtribe or of a larger group is ambiguous (Fig. 33).

Though McPherson \& Tirel (1987) discovered that Scagea is pantoporate, they were impressed by its uniovulate carpels and placed it in the Crotonoideae. Our studies show that Scagea instead belongs in the Pseudanthinae. Pollen ultrastructure of Crotonoideae, though variable, is quite different from that of Scagea (Nowicke, 1994, this issue). As we discussed previously in the section on cladistic analysis of the palynological data, Scagea instead shares the unique ultrastructural synapomorphies of the other Pseudanthinae (except Neoroepera buxifolia; see Fig. 33), notably a thick, homogeneous foot-layer (7: 1; Fig. 36) and a microperforate/granular tectum (9: 3; Fig. 38). So far as is known (its wood has not been examined), Scagea also shares the morphological synapomorphies expected of a genus nested within the Pseudanthinae, making it unlikely that Scagea belongs elsewhere. Specifically, it has chambered epidermal cells (27: 1; Fig. 33) and crenulate anticlinal walls on the subsidiary cells (30: 1; Fig. 31 ), both unique synapomorphies within the Oldfieldioideae; crenulate subsidiary cells are not known elsewhere in the Euphorbiaceae (Hayden, 1994). Also unique in Oldfieldioideae is having the cotyledons narrower than the radicle (23: 1), a synapomorphy shared by Micrantheum, Pseudanthus, and Stachystemon (Fig. 33); seeds of Scagea (and Kairothamnus) should be examined to determine the form of its embryo. Like the other Pseudanthinae, Scagea is monoecious.

On the basis of our data Neoroepera appears to be diphyletic, in that $N$. banksii shares with other Pseudanthinae four synapomorphies that are lacking in N. buxifolia. With Kairothamnus, Scagea, Micrantheum, Pseudanthus, and Stachystemon, N. banksii shares a thick, homogeneous footlayer (7: 1; Fig. 36) and a microperforate/granular tectum (9: 3; Fig. 38), both unique within the 
Oldfieldioideae, and with the last three genera shares thick unlignified phloem fibers in the primary leaf vein $(31: 1)$ and an intramarginal leaf vein (38: 1), both also unique synapomorphies (Fig. 33). Neoroepera buxifolia is the type species, so it appears that a new genus will have to be described to accommodate $N$. banksii (Levin, in prep.).

As we discussed previously when explaining character state coding, it is unclear whether $M i$ crantheum bears sessile compound exstipulate leaves or simple leaves with foliaceous stipules. This cladistic analysis shows that within the Oldfieldioideae compound leaves $(24: 1,2)$ are restricted to the Picrodendreae and loss of stipules (45: 1) to the Dissiliariinae. It is therefore more parsimonious to interpret the leaves of Micrantheum as being simple with foliaceous stipules.

\section{BIOGEOGRAPHY}

The phylogenies shown in Figures 31-33 fit very well with the distribution of the genera (Fig. 35). Croizatia, Paradrypetes, and Podocalyx, which form the basal two clades, are all American, as are Tetracoccus and the four genera we place in the Picrodendrinae, Celaenodendron, Parodiodendron, Picrodendron, and Piranhea. In contrast, Oldfieldia and the Mischodontinae are African and/or Madagascan, with the exception of Mischodon itself which is found in India and Sri Lanka. With the sole exception of the South African endemic Hyaenanche, the remaining genera are all Australasian.

\section{RELATIONSHIPS WITH OTHER EUPHORBIACEAE}

It is clear that Oldfieldioideae are derived from within the Phyllanthoideae (Hayden, 1994; Webster, 1994; Webster et al., 1987). We have not studied the pollen ultrastructure of enough Phyllanthoideae, particularly the relatively basal genera, to be able to use those data to resolve relationships further. Uncertainty about appropriate outgroups also limited resolution of relationships among the Phyllanthoideae we did study and between these taxa and the Oldfieldioideae. At this point we can do little more than speculate that the closest relatives of the Oldfieldioideae are probably among the relatively basal Phyllanthoideae.

As pointed out by Webster et al. (1987), the resemblance between pollen of Amanoa guianensis and Oldfieldioideae is superficial. Though the pollen of $A$. guianensis may appear to be echinate with verrucate nonspinal sculpturing (Webster et al., 1987: fig. 7), the pollen has a thin, continuous foot-layer (7: 0) like other Phyllanthoideae. Fur- thermore, pollen of $A$. guianensis is intectate: the verrucae and round-ended spines-or baculaeoriginate from the foot-layer rather than the tectum (Fig. 14). Thus the pollen of $A$. guianensis does not support a close relationship between this species and the Oldfieldioideae. Instead, $A$. guianensis appears to be a derived species within a genus that otherwise has tectate-reticulate pollen (Simpson \& Levin, in prep.; Köhler, 1965; Punt, 1962), as seen, for example, in A. strobilacea (Fig. 15).

\section{Recommendations for Future Research}

This study confirms that pollen studies using TEM, like those using LM and SEM, can contribute data of systematic significance for the Euphorbiaceae. Nowicke's (1994) study of Crotonoideae provides additional evidence for the utility of TEM data. Given our ignorance of pollen ultrastructure throughout most of the family, we recommend starting with general surveys of the remaining three subfamilies, paying particular attention to relatively basal genera in the various lineages.

By combining our pollen data with the excellent data on the vegetative morphology and anatomy obtained by Hayden (1980, 1994), we have been able to propose a strong hypothesis for the phylogeny of the Oldfieldioideae. Unfortunately we have largely neglected reproductive morphology in our analysis. This is due in large part to inconsistent descriptions and lack of published data. There is a pressing need for a careful comprehensive review of reproductive morphology throughout the Oldfieldioideae. When those data are available, systematists can further test and refine the phylogeny and classification we have proposed.

Certain taxa also require further study of their vegetative anatomy because these data currently are unavailable (see Table 3). Critical among these taxa is Croizatia because of its apparently basal position within the subfamily; both its wood and foliar anatomy are poorly known. Other taxa requiring further study are Kairothamnus, Longetia, Scagea, and Stachystemon, for all of which we lack data on wood anatomy, and Voatamalo, for which we lack data on foliar morphology and anatomy.

Chromosome numbers are known for only two species in the Oldfieldioideae, Mischodon zeylanicus and Tetracoccus fasciculatus (S. Watson) Croizat. Both have $x=12$ (Datta, 1967; Perry, 1943; Sarkar \& Datta, 1980), whereas the base number for most Phyllanthoideae is $x=13$ (Hans, 1973). Chromosome counts for more Oldfieldioideae are needed to determine if chromosome num- 
ber provides an additional synapomorphy for the subfamily, further clarifying its limits.

\section{Literature Cited}

Agardh, C. A. 1858. Theoria Systematis Plantarum. Gleerup, Lund.

Airy Shaw, H. K. 1970. The genus Androstachys Prain in Madagascar. Adansonia, sér. 2, 10: 519524.

1972. A second species of the genus Aristogeitonia Prain (Euphorbiaceae) from East Africa. Kew Bull. 26: 495-498.

- 1974. Notes on Malesian and other Asiatic Euphorbiaceae. CLXXV. New species of Austrobuxus Miq., with a key to the whole genus. Kew Bull. 29: $303-309$.

- 1976. New or noteworthy Australian Euphorbiaceae. Kew Bull. 31: 341-398.

- 1980. New Euphorbiaceae from New Guinea. Kew Bull. 34: 591-598.

Bonnefille, R. \& G. Riollet. 1980. Pollens des Savanes d'Afrique Oriental. Centre National de la Recherche Scientifique, Paris.

Bosser, J. 1976. Voatamalo, nouveau genre d'Euphorbiaceae de Madagascar. Adansonia, sér. 2, 15: 333-340.

Chase, M. W., W. R. Anderson \& H. G. Hills. 1991. Molecular systematics of the Malpighiaceae and "middle rosid" families: An analysis of variation in gene sequences from the chloroplast gene $r b c \mathrm{~L}$. Amer. J. Bot. 78(6, supplement): 170 .

Cronquist, A. 1981. The Evolution and Classification of Flowering Plants. Houghton Mifflin, Boston, Massachusetts.

DAHLGREN, R. 1983. General aspects of angiosperm evolution and macrosystematics. Nordic J. Bot. 3: 119-149.

\& A. E. VAN WYK. 1988. Structures and relationships of families endemic to or centered in southern Africa. Monogr. Syst. Bot. Missouri Bot. Gard. 25: 1-94.

DatTA, N. 1967. In: A. Löve (editor), IOPB Chromosome Number Reports XII. Taxon 16: 341-350.

Dechamps, R., M. Mosango \& E. RobBrecht. 1985. Etudes systématiques sur les Hymenocardiaceae d'Afrique: La morphologie du pollen et l'anatomie du bois. Bull. Jard. Bot. Etat 55: 473-485.

Donoghue, M. J. \& P. D. Cantino. 1984. The logic and limitations of the outgroup substitution approach to cladistic analysis. Syst. Bot. 9: 192-202.

El-Ghazaly, G. \& B. Raj. 1986. A contribution to the pollen morphology of Andrachne (Euphorbiaceae). Pollen \& Spores 28: 297-310.

Erdtman, G. 1952. Pollen Morphology and Plant Taxonomy, Angiosperms. Almqvist \& Wiksell, Stockholm.

FARRIS, J. S. 1969. A successive approximations approach to character weighting. Syst. Zool. 18: 374385 .

- 1988. Hennig86, ver. 1.5. Computer program distributed by James S. Farris, Port Jefferson Station, New York.

Hans, A. S. 1973. Chromosomal conspectus of the Euphorbiaceae. Taxon 22: 591-636.

HAYDEN, W. J. 1977. Comparative anatomy and sys- tematics of Picrodendron, genus incertae sedis. J. Arnold Arbor. 58: 257-279.

- 1980. Systematic anatomy of Oldfieldioideae (Euphorbiaceae). Unpublished Ph.D. Dissertation. Univ. Maryland, College Park.

- 1994. Systematic anatomy of Euphorbiaceae subfamily Oldfieldioideae. I. Overview. Ann. Missouri Bot. Gard. 81: 000-000.

- W. T. Gillis, D. E. Stone, C. R. Broome \& G. L. Webster. 1984. Systematics and palynology of Picrodendron: Further evidence for relationship with the Oldfieldioideae (Euphorbiaceae). J. Arnold Arbor. 65: 105-127.

HERR, J. M., JR. 1971. A new clearing-squash technique for the study of ovule development in angiosperms. Amer. J. Bot. 58: 785-790.

HiCKEY, L. J. 1979. A revised classification of the architecture of dicotyledonous leaves. Pp. 25-39 in C. R. Metcalfe \& L. Chalk (editors), Anatomy of the Dicotyledons, 2nd ed., Vol. 1. Clarendon Press, Oxford.

— \& J. A. WOLFE. 1975. The bases of angiosperm phylogeny: Vegetative morphology. Ann. Missouri Bot. Gard. 62: 538-589.

Hutchinson, J. 1969. Tribalism in the family Euphorbiaceae. Amer. J. Bot. 56: 738-758.

Jussieu, A. H. L. DE. 1824. De Euphorbiacearum Generibus Medicisque Earumdem Viribus Tentamen. Didot, Paris.

KöHLER, E. 1965. Die Pollenmorphologie der Biovulaten Euphorbiaceae und ihre Bedeutung für die Taxonomie. Grana Palynol. 6: 26-120.

Kuhlmann, J. G. 1935. Novas especies da Hylea. Arq. Inst. Biol. Veg. 2: 83-89.

—. 1940. Especies novas equatoriais. Anais Reunião Sul.-Amer. Bot. 3: 78-86.

LEROY, J.-F. 1976. Recherches sur la nature et l'origine de la fleur angiospermienne: Interprétation des structures dans un groupe singulier d'Euphorbiaceae. Compt. Rend. Hebd. Séances Acad. Sci., Sér. D, 283: 147-150.

Levin, G. A. 1986a. Systematic foliar morphology of Phyllanthoideae (Euphorbiaceae). I. Conspectus. Ann. Missouri Bot. Gard. 73: 29-85.

— 1 1986b. Systematic foliar morphology of Phyllanthoideae (Euphorbiaceae). II. Phenetic analysis. Ann. Missouri Bot. Gard. 73: 86-98.

- 1986c. Systematic foliar morphology of Phyllanthoideae (Euphorbiaceae). III. Cladistic analysis. Syst. Bot. 11: 515-530.

1992. Systematics of Paradrypetes (Euphorbiaceae). Syst. Bot. 17: 74-83.

- \& M. G. Simpson. 1994. Phylogenetic relationships of Didymocistus and Hymenocardia (Euphorbiaceae). Ann. Missouri Bot. Gard. 81: 239244.

Maddison, W. P. \& D. R. Maddison. 1992. MacClade: Analysis of Phylogeny and Character Evolution, ver. 3.0. Sinauer Associates, Sunderland, Massachusetts. , M. J. Donoghue \& D. R. MADDison. 1984. Outgroup analysis and parsimony. Syst. Zool. 33: 83-103.

Martin, H. A. 1974. The identification of some Tertiary pollen belonging to the family Euphorbiaceae. Austral. J. Bot. 22: 271-291.

Matos Araujo, P. A. DE \& A. DE Mattos Filho. 1984. Estrutura das madeiras brasileiras de Dicotiledô- 
neas-XXVI. Euphorbiaceae. Rodriguésia 36: 2540.

McPherson, G. 1985. Scagea, a new genus of Euphorbiaceae from New Caledonia. Bull. Mus. Hist. Nat. (Paris), sér. 4, sect. B, Adansonia 7: 247-250.

— \& G. TIREL. 1987. Euphorbiaceae. I. Euphorbioideae, Crotonoideae, Acalyphoideae, Oldfieldioideae. In: P. Morat \& H. S. Mackee (editors), Flore de la Nouvelle-Calédonie et Dépendances 14: 1-226. Muséum National d'Histoire Naturelle, Paris.

Mennega, A. M. W. 1984. Wood structure of $\mathrm{Ja}$ blonskia congesta (Euphorbiaceae). Syst. Bot. 9: 236-239.

- 1987. Wood anatomy of the Euphorbiaceae, in particular of the subfamily Phyllanthoideae. J. Linn. Soc., Bot. 94: 111-126.

Metcalfe, C. R. \& L. Chalk. 1950. Anatomy of the Dicotyledons, 1st ed., Vol. 2. Oxford Univ. Press, Oxford.

Milanez, F. R. 1935. Anatomia de Paradrypetes ilicifolia. Arq. Inst. Biol. Veg. 2: 133-156.

NowicKe, J. 1994. A palynological study of Crotonoideae (Euphorbiaceae). Ann. Missouri Bot. Gard. 81: $245-269$.

Pax, F. \& K. Hoffmann. 1922. Euphorbiaceae-Phyllanthoideae-Phyllantheae. In: A. Engler (editor), Das Pflanzenreich, IV, 147. XV (Heft 81): 1-349.

$\longrightarrow \&-1931$. Euphorbiaceae. In: A. Engler \& K. Prantl (editors), Die Natürlichen Pflanzenfamilien, ed. 2, 19c: 11-233.

Perry, B. A. 1943. Chromosome number and phylogenetic relationships in the Euphorbiaceae. Amer. J. Bot. 30: 527-543.

Poole, M. M. 1981. Pollen diversity in Zimmermannia (Euphorbiaceae). Kew Bull. 36: 129-138.

PunT, W. 1962. Pollen morphology of the Euphorbiaceae with special reference to taxonomy. Wentia 7: $1-116$.

- 1980. Pollen morphology of the Phyllanthus species (Euphorbiaceae) occurring in New Guinea. Rev. Palaeobot. Palynol. 31: 155-177.

- 1987. A survey of pollen morphology in Euphorbiaceae with special reference to Phyllanthus. J. Linn. Soc., Bot. 94: 127-142.

RadCliffe-Smith, A. 1987a. Euphorbiaceae (Part 1). In: R. M. Polhill (editor), Flora of Tropical East Africa. A. A. Balkema, Rotterdam.

- 1987b. Notes on Madagascan Euphorbiaceae. I. On the identity of Paragelonium and on the affinities of Benoistia and Claoxylopsis (Euphorbiaceae). Kew Bull. 43: 625-647.

- 1990. Notes on Madagascan Euphorbiaceae. III. Stachyandra. Kew Bull. 45: 561-568.

Radford, A. E., W. C. Dickison, J. R. Massey \& C. R. BELL. 1974. Vascular Plant Systematics. Harper \& Row, New York.
ReITSma, T. 1970. Suggestions towards unification of descriptive terminology of angiosperm pollen grains. Rev. Palaeobiol. Palynol. 10: 39-60.

SARKaR, A. K. \& N. DatTa. 1980. Cytological assessment of the family Euphorbiaceae. II. Tribe Phyllantheae. Proc. Indian Sci. Congr. Assoc. (III, C) 67: 48-4.9.

Simpson, M. G. \& G. A. Levin. Pollen ultrastructure of the biovulate Euphorbiaceae. Int. J. Pl. Sci. (in press).

SPURR, A. 1969. A low-viscosity epoxy resin embedding medium for electron microscopy. J. Ultrastruct. Res. 26: $31-43$.

Standley, P. C. 1927. Celaenodendron. Pp. 76-77 in R. S. Ferris (editor), Preliminary Report on the Flora of the Tres Marías Islands. Contr. Dudley Herb. 1: 63-88.

Stevens, P. F. 1991. Character states, morphological variation, and phylogenetic analysis: A review. Syst. Bot. 16: 553-583.

Swofford, D. L. 1993. PAUP: Phylogenetic Analysis Using Parsimony, ver. 3.1. Computer program distributed by the Illinois Natural History Survey, Champaign, Illinois.

Takhtajan, A. 1980. Outline of the classification of flowering plants (Magnoliophyta). Bot. Rev. 46: 225359.

ThorNe, R. T. 1983. Proposed new realignments in the angiosperms. Nordic J. Bot. 3: 85-117.

Walker, J. W. \& J. A. Doyle. 1975. The bases of angiosperm phylogeny: Palynology. Ann. Missouri Bot. Gard. 62: 664-723.

WEBSTER, G. L. 1967. The genera of Euphorbiaceae in the southeastern United States. J. Arnold Arbor. 48: 303-430.

1975. Conspectus of a new classification of the Euphorbiaceae. Taxon 24: 593-601. - 1984. Jablonskia, a new genus of Euphorbiaceae from South America. Syst. Bot. 9: 229-235. 1987. The saga of the spurges: A review of classification and relationships in the Euphorbiales. J. Linn. Soc., Bot. 94: 2-46.

- 1994. Synopsis of the suprageneric taxa of Euphorbiaceae. Ann. Missouri Bot. Gard. 81: 000000 .

—, L. Gillespie \& J. Steyermark. 1987. Systematics of Croizatia (Euphorbiaceae). Syst. Bot. 12: $1-8$.

WILEY, E. O. 1979. An annotated Linnean hierarchy, with comments on natural taxa and competing systems. Syst. Zool. 28: 308-337.

- 1981. Phylogenetics. The theory and practice of phylogenetic systematics. John Wiley \& Sons, New York. 